\title{
Nutraceuticals against Oxidative Stress in Autoimmune Disorders
}

\author{
Carmen Mannucci ${ }^{1}$, Marco Casciaro ${ }^{2, *}$ () , Emanuela Elisa Sorbara ${ }^{1}$, Fabrizio Calapai ${ }^{3}{ }^{(}$, Eleonora Di Salvo ${ }^{4}$, \\ Giovanni Pioggia ${ }^{5}$, Michele Navarra ${ }^{3}{ }^{-}$, Gioacchino Calapai ${ }^{1}$ and Sebastiano Gangemi ${ }^{2}$
}

1 Department of Biomedical and Dental Sciences and Morphofunctional Imaging, University of Messina, 98125 Messina, Italy; carmen.mannucci@unime.it (C.M.); emanuela.sorbara@hotmail.it (E.E.S.); gioacchino.calapai@unime.it (G.C.)

2 Department of Clinical and Experimental Medicine, Unit and School of Allergy and Clinical Immunology, University of Messina, 98125 Messina, Italy; gangemis@unime.it

3 Department of Chemical, Biological, Pharmaceutical and Environmental Sciences, University of Messina, 98168 Messina, Italy; f.calapai@gmail.com (F.C.); michele.navarra@unime.it (M.N.)

4 Department of Veterinary Sciences, University of Messina, 98168 Messina, Italy; edisalvo@unime.it

5 Institute for Biomedical Research and Innovation (IRIB), National Research Council of Italy (CNR), 98164 Messina, Italy; giovanni.pioggia@cnr.it

* Correspondence: mcasciaro@unime.it; Tel.: +39-090-221-2013

Citation: Mannucci, C.; Casciaro, M.; Sorbara, E.E.; Calapai, F.; Di Salvo, E.; Pioggia, G.; Navarra, M.; Calapai, G.; Gangemi, S. Nutraceuticals against Oxidative Stress in Autoimmune

Disorders. Antioxidants 2021, 10, 261. https://doi.org/10.3390/antiox10020261

Academic Editor: Yoko Ozawa

Received: 26 November 2020

Accepted: 4 February 2021

Published: 8 February 2021

Publisher's Note: MDPI stays neutral with regard to jurisdictional claims in published maps and institutional affiliations.

Copyright: (c) 2021 by the authors. Licensee MDPI, Basel, Switzerland. This article is an open access article distributed under the terms and conditions of the Creative Commons Attribution (CC BY) license (https:// creativecommons.org/licenses/by/ $4.0 /)$.

\begin{abstract}
Antioxidant mechanisms are constituted of enzymes, endogenous, and non-enzymatic, exogenous, which have the role of counterbalancing oxidative stress. Intake of these compounds occurs in the diet. Vegetables, plants, and fruits contain a wide range of alkaloids, polyphenols, and terpenoids which are called "phytochemicals". Most of these substances are responsible for the positive properties of fruits and vegetables, which are an essential part of a healthy life with roles in ameliorating chronic illnesses and favoring longevity. Nutraceuticals are substances contained in a food or fragment of it influencing health with positive effects on health helping in precenting or treating disorders. We conducted a review illustrating the principal applications of nutraceuticals in autoimmune disorders. Literature reported several studies about exogenous dietary antioxidant supplementation in diverse autoimmune diseases such as rheumatoid arthritis, lupus, diabetes, and multiple sclerosis. In these pathologies, promising results were obtained in some cases. Positive outcomes were generally associated with a reduction of oxidative stress parameters and a boost to antioxidant systems, and sometimes with anti-inflammatory effects. The administration of exogenous substances through food derivates or dietary supplements following scientific standardization was demonstrated to be effective. Further bias-free and extended studies should be conducted that include ever-increasing oxidative stress biomarkers.
\end{abstract}

Keywords: nutraceuticals; oxidative stress; immunity; autoimmune; ROS; supplement; inflammation; integrators; diabetes; exogenous antioxidants

\section{Introduction}

Reactive oxygen species (ROS) represent a class of molecules capable of damaging DNA. They are almost always present in the human body since they are produced by cellular metabolism in response to toxic factors or after the intervention of external phenomena. Superoxide anion radicals $\left(\mathrm{O}_{2}{ }^{-}\right)$, hydrogen peroxide $\left(\mathrm{H}_{2} \mathrm{O}_{2}\right)$, hydroxyl radicals $(\mathrm{OH})$, and singlet oxygen $\left(\mathrm{O}_{2}\right)$ are only some of the chemical products belonging to the ROS family [1].

ROS can be augmented by multiple factors and/or due to impaired antioxidant defenses. The loss of redox homeostasis generates stressed cells which in turn produce damage-associated molecular patterns (DAMPs) or autoantigens that could initiate innate immunity and adaptive immunity. This series of events leads to the dysfunction and death of cells via an inflammatory cascade. Oxidative stress and autoimmunity with genetic susceptibility are associated with the pathogenesis of several autoimmune diseases; 
however, precisely how these two pathways integrate one with each other is not fully understood $[2,3]$ The etiology of autoimmune diseases is many due to genetic and environmental factors. Their prevalence is between the $0.33 \%$ and $2 \%$. Disease severity and symptoms like pain are intimately connected to inflammation and oxidative stress. Innate immunity appears to be one main actor in autoimmunity which causes disease progression. Patients suffering from several immune-related diseases such as rheumatoid arthritis (RA), systemic lupus erythematosus (SLE), multiple sclerosis (MS), and diabetes mellitus (DM) type 1 have an altered Type 1 helper (Th1)/Type 2 helper (Th2) activity ratio, augmented Type 17 helper (Th17) responses, as well as Type 0 helper (Th0) and Th1 cytokines serum levels [4].

Antioxidant mechanisms are constituted of enzymes which counterbalance ROS effects. The most studied are superoxide dismutase (SOD), catalase (CAT), glutathione peroxidase (GPx), and myeloperoxidase (MPO). The aim of these mechanisms is the transformation of radicals into less harmful molecules. There are also non-enzymatic and exogenous antioxidants which counterbalance oxidative stress $[5,6]$. Intake of these compounds occurs in the diet and includes $\mathrm{E}$ and $\mathrm{C}$ vitamins, carotenoids, and flavonoids [7]. Vegetables, plants, and fruits contain a wide range of alkaloids, polyphenols, and terpenoids which are called "phytochemicals". Most of these substances are responsible for the positive properties of fruits and vegetables, which are an essential part of a healthy life with roles in ameliorating chronic illnesses and favoring longevity [8]. The Mediterranean diet, rich in these nutrients, is associated with a reduced incidence of chronic diseases [9]. Moreover, although phytochemicals can generate hormetic positive effects on aging and on chronic illnesses, various botanical formulations have been characterized for their citoxicity and apoptosis-inducing activity [10].

Exogenous antioxidants could be introduced in the human body through several compounds, either natural or artificial. However, their efficacy has not completely been demonstrated in relation to immune system alterations. In this review, we focused on the latest evidence of the ability of nutraceuticals to influence the formation of ROS in autoimmune diseases.

The term 'nutraceutical' was invented in 1989 by Stephen L. Defelice, who established The Foundation for Innovation in Medicine in 1976. There is no internationally recognized definition of a nutraceutical, and various confusing and contradictory definitions have appeared.

Nutraceuticals are substances contained in a food that have positive effects on health and help in preventing or treating disorders [11]. Their positive effect in many health problems, such as cancer, inflammation, hypertension, cardiovascular diseases, atherosclerosis, obesity, and diabetes, has been previously shown [12]. Moreover, several clinical studies on nutraceuticals have been carried out and results support the effectiveness of nutraceuticals as well as their general safety [13].

Nutraceuticals are also defined by European Nutraceutical Association as 'nutritional products which have effects that are relevant to health which are not synthetic substances or chemical compounds formulated for specific indications containing nutrients partly in concentrated form [14]. ENA declares that also the terms dietary supplements, dietetic and functional foods are referred as nutraceuticals and they form a common category [15].

In the light of the above-mentioned concepts, we wrote a narrative review illustrating the applications of principal nutraceuticals in autoimmune disorders.

Electronic databases PubMed, Scopus, and ScienceDirect were used. In this review, we collected and discussed scientific articles published in peer-reviewed journals written in the English language until December 2020 describing the use of nutraceutical products in autoimmune disorders. On the basis of bibliographic research, we commented those nutraceuticals used for autoimmune disorders on which the strongest evidence is present in the scientific literature: exogenous antioxidants (vitamins, flavonoids, coenzymes Q9 and Q10), probiotics, medicinal plants (Allium sativum, Ricinus communis, Origanum vulgare, Curcuma longa), lichen species, melatonin, arginine, omega-3, minerals (selenium, zinc). 


\section{Exogenous Antioxidants}

Exogenous antioxidants are fundamental in counterbalancing oxidative stress. These compounds intake happen thanks to diet and include some of the principles listed above. The chemical structure of the principal exogenous antioxidants was represented in a Supplementary Figure S1.

\subsection{Vitamins}

Vitamin E is an effective antioxidant, having 8 isoforms. Vitamin E is co-localized in the mitochondrial membrane and works as peroxyl radical scavenger. Research demonstrated the presence of doubled $\alpha$-tocopherol concentration in non-asthmatics compared to asthmatic subjects [16].

Vitamin $C$ exert its action in collaboration with vitamin E. It eliminates excessive radicals and restores vitamin $\mathrm{E}$ to its original form [17].

Carotenoids include $\beta$-carotene, introduced with the diet (i.e., carrots, lettuce, fruit). Once in the body, it is transformed in retinol (fundamental for eye physiology). It protects against the singlet oxygen [18].

Vitamin D is a secosteroid hormone. Its D3 form (cholecalciferol) derives from the skin after intervention of ultraviolet B-light. Its levels are determined mainly from this pathway than from the diet [19]. It has strong healthy effects by acting through the its nuclear receptor in several diseases: osteoporosis, cancer, and autoimmune diseases [20,21]. Vitamin $\mathrm{D}$ effects are mainly due to its immune balancing ability, antioxidant and anti-fibrotic activities [19]. Low levels of vitamin D is considered a key factor inducing autoimmune diseases. It has been observed that its supplementation prevents and ameliorates these pathologies [22].

\subsection{Flavonoids}

Flavonoids are typical components of plants (such as green tea leaves and grapes). They are polyphenolic substances constituted by 3 rings: 2 aromatics, A and B and a heterocyclic one, $\mathrm{C}$. Some of them in alternative to the $\mathrm{C}$ ring could have an open chain of three carbon atoms. The oxidation and degree of unsaturation of ring $\mathrm{C}$ determines the subclass: flavonols and flavones, flavanols, (or catechins), flavanones, anthocyanins, and isoflavones [23].

They have protective effects in autoimmune diseases [24]. Flavonoids exert the renowned beneficial effect in human by targeting multiple cell systems. Nitric oxide (NO) and reactive oxygen species (ROS) are some of their targets thanks to their ability to ameliorate antioxidant enzymes, like inducible nitric oxide synthase (iNOS) and cyclooxygenases (COXs) [25,26].

\subsection{Coenzyme $Q 9$ and $Q 10(C o Q)$}

Coenzyme Q (CoQ) is arousing lot of interest about its actions as antioxidant in the fight against ROS. Coenzyme Q10 (ubiquinone) is an electron carrier and has a function as protein translocator. Once transformed in ubiquinol it regenerate vitamin $\mathrm{E}$ acting as a key player as antioxidant [27-29]. CoQ homologues have a different number due to their isoprenoid units (Qn) bind at the 6-position on the benzoquinone ring of the coenzyme $Q$ moiety. In the human body, Q9 and Q10 are present in several organs such as kidney, brain, liver, heart, blood, and cutis [30]. Intracellularly, the different organelles have different concentrations of CoQ. Diabetic patients have an increased vulnerability to oxidative stress due to a minor concentration of the Q9 and Q10 coenzymes in the mitochondria. They showed protective effects after ischemic events [31].

\section{Probiotics}

Probiotics administration was demonstrated having positive effects on several immune related diseases. Among these, for sure rheumatoid arthritis, ulcerative colitis, multiple sclerosis, and hepatic encephalopathy were certainly influenced [32]. Considering 
different phyla, Lactobacilli and Bifidobacteria were effective in the balance between Treg and Th17 action. Moreover, in some lung diseases like asthma and COPD probiotics administration ameliorated oxidative stress status [32-34]. Literature data suggested the existence of a bidirectional axis between gut microbiota and some organs (i.e., lung, brain). In this scenario, Lactobacilli and Bifidobacteria are the main actors in reducing chronic inflammation mediators [35].

\section{Medicinal Plants}

Remedies based on plant extracts were used for centuries in folk medicine. During the last decades, modern science focused on the identification of bioactive plant chemical compounds able to produce effects influencing positively human physiology. In fact, some of the most fundamental treatments directly derives from natural components. Individuating potential plant-based drugs aroused a lot of interest in last years and it became a challenge for many researchers [36]. Among plants showing effects on immune system, we chose six of the most investigated.

\subsection{Allium Sativum}

Allium sativum, commonly known as garlic, was reported as having several beneficial effects. It is well tolerated even though it could be detrimental for the stomach when taken at high doses. It has disinfectant properties acting on bacteria, fungus, and parasites. It was demonstrated as having metabolic effects also, ameliorating glucose absorption, and diminishing cholesterol. Anti-neoplastic actions were reported. Its cooked and waited extracts and oils might offer an improved antioxidant effect versus fresh garlic [37-39].

\subsection{Ricinus Communis}

Ricinus communis L. (Euphorbiaceae) is arousing a lot of interest as an anti-neoplastic agent. It is famous among common people as castor plant and it was used in traditional Indian medicine for [40]. Other data highlighted its effectiveness against fungi and pests [41].

\subsection{Origanum Vulgare}

Distributed worldwide, Origanum vulgare (Lamiaceae) is used almost everywhere as a spice. It is also a component of traditional medicine for common pathologies like respiratory illness and intestinal diseases [42]. Antimicrobial and antioxidant abilities were also attributed to this plant. Probably, its elevated concentration of volatile oils gives to the plant its antimicrobial potential [43]. It has phenolic compounds including flavonoids and phenolic acids, with a strong antioxidant activity.

\subsection{Curcuma Longa (Curcumin)}

Curcumin is a polyphenolic substance contained in the rhizome of Curcuma longa. It is employed as analgesic and wound-repairing agent. Recently findings carried out in humans and laboratory animals reported that curcumin improves autoimmune diseases such as rheumatoid arthritis, multiple sclerosis, psoriasis, and inflammatory bowel disease. Curcumin protective activity in these diseases seems to be due to modulation of inflammatory cytokines and associated signaling pathways in immune cells [44].

\section{Lichen Species}

Lichens also belong to traditional medicine heritage. The products of transformation generated by lichen are the reason of this therapeutic potential. Among these, phenolic molecules are some of these secondary metabolites and the best tested. These metabolites can be categorized in: depsides, depsidones, dibenzofurans, and pulvinic acid derivatives. They demonstrated antioxidants abilities by boosting endogenous enzymatic defenses and non-enzymatic mechanisms [45]. 


\section{Melatonin}

It is a hormone produced by the pineal gland with a fundamental role in the regulation of the circadian rhythm. During the last decades it has exerted a lot of interest due to its direct antioxidant properties by a scavenger action and by the induction of genes related to antioxidant system activity $[46,47]$.

\section{Arginine}

L-arginine is for humans an essential amino acid with a series of fundamental biological functions during its metabolism. During the last 20 years it emerged its role in ameliorating oxidative stress tolerance and in balancing immunity. The exact antioxidant mechanisms remain still unclear but some hypothesis were conducted on the basis of its potential as a booster of endogenous antioxidant defenses [48].

\section{Omega-3}

In the last years, growing evidence coming from genetic mouse models and clinical studies highlighted the role and underlying mechanisms of $\omega-3$ polyunsaturated fatty acids and their metabolites in the prevention and therapy of autoimmune pathologies such as rheumatoid arthritis, systemic lupus erythematosus, type 1 diabetes, and multiple sclerosis [49].

\section{Minerals}

\subsection{Selenium}

Selenium is an essential micronutrient playing a key role in physiology including regulation of immune activity [50]. Intake of selenium may reduce circulating thyroid autoantibodies in subjects affected by chronic autoimmune thyroiditis [51].

\subsection{Zinc}

Zinc is a trace element essential for living organisms with a fundamental role in enzymatic activity and cellular communication, proliferation and differentiation. Zinc has a role also in modulating the immune system. It has been proved the existence of a deficiency of zinc in patients affected by autoimmune diseases [52].

\section{Autoimmune Diseases}

According to the different areas involved in the research, articles were divided and discussed as follows (Tables 1 and 2): 
Table 1. Clinical studies supporting the use of the exogenous antioxidant compounds (considered), in autoimmune diseases.

\begin{tabular}{|c|c|c|c|c|c|}
\hline $\begin{array}{c}\text { Exogenous Antioxidant } \\
\text { (Compound) }\end{array}$ & Study Design & Study Protocol & Proncipal Endpoint & Observed Effect (Outcome) & Reference \\
\hline \multirow[b]{2}{*}{ Alpha-lipoic acid } & $\begin{array}{l}\text { Randomized, double-blind, } \\
\text { placebo-controlled clinical trial }\end{array}$ & $\begin{array}{l}\text { Patients affected by Rheumathoid } \\
\text { arthritis (RA) }(n=70 \text { ) (age range } \\
20-50 \text { years) were randomly assigned } \\
1: 1 \text { to receive } 2 \text { capsules a day, every } \\
12 \mathrm{~h}, 30 \mathrm{~min} \text { prior to breakfast and } \\
\text { dinner either Alpha lipoic acid (ALA) } \\
\text { ( } 1200 \mathrm{mg} / \text { day) or placebo } \\
\text { (maltodestrin } 600 \mathrm{mg} \text { ) for } 8 \text { weeks. }\end{array}$ & $\begin{array}{l}\text { Inflammatory biomarkers [serum } \\
\text { high-sensitivity C-reactive protein } \\
\text { (hs-CRP), tumor necrosis factor-alpha } \\
\text { (TNF- } \alpha \text { ), interleukin-6(IL-6), and } \\
\text { serum matrix metalloproteinase-3 } \\
\text { (MMP-3)]. Moreover, 3-day dietary } \\
\text { records, the International Physical } \\
\text { Activity Questionnaire (IPAQ), and } \\
\text { the Spielberger State-Trait anxiety } \\
\text { inventory form Y (STAI-Y) were } \\
\text { evaluated before and after the } \\
\text { intervention. }\end{array}$ & $\begin{array}{l}\text { No statistically significant differences } \\
\text { were observed in serum levels of } \\
\text { hs-CRP, TNFF- } \alpha \text {, I- } 6 \text {, and MMP-3 } \\
\text { within and between the ALA and } \\
\text { placebo groups }(p>0.05) \text {. There were } \\
\text { no statistically significant differences } \\
\text { in dietary intakes, physical activity, } \\
\text { and anxiety levels between groups at } \\
\text { baseline and during the study period } \\
(p>0.05) \text {. }\end{array}$ & $\begin{array}{l}\text { Mirtaheri et al., } 2015 \\
{[53]}\end{array}$ \\
\hline & $\begin{array}{l}\text { Prospective, randomized, } \\
\text { double-blind, controlled trial }\end{array}$ & $\begin{array}{l}\text { Seventy-one children and adolescents } \\
\text { (mean age } 17 \pm 3.9 \text { yrs), with type } \\
1 \text { diabetes, were randomized into } \\
3 \text { arms: } 10.000 \text { oxygen radical } \\
\text { absorbance capacity units (ORAC) } \\
\text { antioxidant diet plus alpha-lipoic } \\
\text { acid }(400 \mathrm{mg})(n=25 \text {, group } 1), 10.000 \\
\text { ORAC antioxidant diet plus placebo } \\
(n=27, \text { group } 2) \text {, and controls }(n=19, \\
\text { group } 3) \text {, with no changes in dietary } \\
\text { habits. Treatment was administered } \\
\text { twice a day at least } 1 \mathrm{~h} \text { before lunch } \\
\text { and dinner, for } 6 \text { months. }\end{array}$ & $\begin{array}{l}\text { Improvement in endothelial } \\
\text { dysfunction measured as mean of } \\
\text { reactive hyperemia index (RHI) }\end{array}$ & $\begin{array}{l}\text { At } 6 \text { months, RHI score was } \\
\text { significantly improved only in the } \\
\text { group of patients treated with } \\
\text { antioxidant diet plus ALA }(p=0.045) \text {, } \\
\text { reaching a normal RHI value. The } \\
\text { group of patients treated with } \\
\text { antioxidant diet plus placebo } \\
\text { reported a better RHI score at } \\
6 \text { months versus baseline as well, but } \\
\text { it did not reach the significance. No } \\
\text { differences in RHI score were showed } \\
\text { in the control group at } 6 \text { months } \\
\text { versus baseline. }\end{array}$ & $\begin{array}{l}\text { Scaramuzza et al., } 2015 \\
{[54]}\end{array}$ \\
\hline Arginine & $\begin{array}{l}\text { double-blind, randomized controlled } \\
\text { clinical trial }\end{array}$ & $\begin{array}{l}44 \text { patients with rheumatoid arthritis } \\
\text { were recruited (age range } 18-65 \\
\text { years). Patients received daily a } \\
100 \mathrm{mg} \text { capsule of CoQ10) }(n=27) \text { or } \\
\text { placebo (wheat starch) }(n=27) \text { for } 2 \\
\text { months in addition to their } \\
\text { conventional medications. }\end{array}$ & $\begin{array}{l}\text { Measure malondialdehyde (MDA), } \\
\text { total antioxidant capacity (TAC), } \\
\text { interleukin (IL)-6 and tumor necrosis } \\
\text { factor alpha (TNF- } \alpha \text { ). }\end{array}$ & $\begin{array}{l}\text { Serum MDA significantly decreased } \\
\text { in supplemented group (mean } \\
\text { difference }=-1.47 \mathrm{nmol} / \mathrm{mL} ; 95 \% \\
\text { confidence interval (CI), }-2.52 \text { to } \\
-0.43 ; ; p=0.008) \text {. CoQ10 also } \\
\text { suppressed overexpression of TNF- } \alpha \\
\text { (difference in median was }+1.1 \text { in } \\
\text { placebo vs. } 0.03 \text { in COQ10 } \mathrm{Croup} ; \\
p=0.033 \text { ). There was no significant } \\
\text { difference in TAC and IL-6 levels } \\
\text { between groups. }\end{array}$ & Abdollahzaet al., 2015 [56] \\
\hline
\end{tabular}


Table 1. Cont

\begin{tabular}{|c|c|c|c|c|c|}
\hline $\begin{array}{c}\begin{array}{c}\text { Exogenous Antioxidant } \\
\text { (Compound) }\end{array} \\
\text { (C) }\end{array}$ & Study Design & Study Protocol & Proncipal Endpoint & Observed Effect (Outcome) & Reference \\
\hline \multirow{3}{*}{ Coenzyme Q10 } & $\begin{array}{l}\text { Randomized, double-blind, } \\
\text { placebo-controlled clinical study. }\end{array}$ & $\begin{array}{l}48 \text { patients with relapsing-remitting } \\
\text { Multiple sclerosis (MS). Subjects were } \\
\text { randomly assigned to a placebo } \\
\text { group (mean age } 30.9 \pm 7.7 \text { years) } \\
\text { ( } n=24 \text { ) or coenzyme Q10 (CoQ10) } \\
\text { supplemented group (mean age } \\
33.1 \pm 7.6 \text { years) }(n=24) \\
\text { (500 mg/day). The intervention was } \\
\text { administered for } 12 \text { weeks. }\end{array}$ & $\begin{array}{l}\text { Measure inflammatory (tumor } \\
\text { necrosis factor- } \alpha \text { (TNF- } \alpha \text { ), } \\
\text { interleukin (IL)-6, and matrix } \\
\text { metalloproteinase (MMP)-9) and } \\
\text { anti-inflammatory (IL-4 and } \\
\text { TGF- } \beta \text { ) markers. }\end{array}$ & $\begin{array}{l}\text { Supplementation of CoQ10 caused a } \\
\text { statistically siognificant decrease of } \\
\text { TNF- } \alpha \text { levels }(p=0.0003) \text {. CoQ10 } \\
\text { group showed significantly lower } \\
\text { IL-6 levels ( } p=0.037) \text {, compared to } \\
\text { the placebo group. CoQ10 } \\
\text { supplementation also resulted in } \\
\text { decreased serum levels of MMP- } 9 \text { as } \\
\text { compared to the placebo group } \\
\text { ( } p=0.011) \text {. IL- } 4 \text { and TGF- } \beta \text { levels } \\
\text { were not modified by CoQ10 } \\
\text { supplementation. }\end{array}$ & Sanoobar et al., 2015 [57] \\
\hline & $\begin{array}{l}\text { Randomized, double-blinded, } \\
\text { placebo-controlled trial }\end{array}$ & $\begin{array}{l}48 \text { patients were randomly allocated } \\
\text { to two groups: CoQ10 group ( } n=24 ; \\
\text { mean age } 33.1 \pm 7.6 \text { years) and } \\
\text { control (placebo) group }(n=24 ; \\
30.9 \pm 7.7 \text { years). The patients in } \\
\text { CoQ10 group were treated with } \\
\text { CoQ10 at doses of } 500 \mathrm{mg} \text { per day for } \\
3 \text { months, whereas controls received } \\
\text { placebo capsules (with the same } \\
\text { shape and color of CoQ10 capsules). } \\
\text { to determine the effect of CoQ10 } \\
\text { supplement (500 } \mathrm{mg} / \text { day) vs. } \\
\text { placebo for } 12 \text { weeks. }\end{array}$ & $\begin{array}{l}\text { Fatigue symptoms were quantified } \\
\text { by means of fatigue severity scale } \\
\text { (FSS) and the Beck depression } \\
\text { inventory (BDI) was used to assess } \\
\text { depressive symptoms. }\end{array}$ & $\begin{array}{l}\text { A significant decrease of FSS was } \\
\text { observed in CoQ10 group during the } \\
\text { intervention }(p=0.001) \text { and } \\
\text { significant increase of FSS change } \\
\text { was observed within placebo group } \\
(p=0.001) \text {. Repeated measure } \\
\text { analysis of variance showed a } \\
\text { significant time-by-treatment } \\
\text { interaction for FSS }(p<0.001) \text { and } \\
\text { BDI }(p<0.001) \text {, indicating significant } \\
\text { decrease of FSS and BDI in CoQ10 } \\
\text { group compared to placebo group. }\end{array}$ & $\begin{array}{c}\text { Sanoobar et al., } 2015 \\
{[58]}\end{array}$ \\
\hline & Controlled clinical trial & $\begin{array}{l}\text { A total of } 58 \text { patients with diabetes }(n \\
=27, \text { T1DM and } n=31, T 2 D M) \text {, and } \\
19 \text { healthy controls were recruited. } \\
\text { (Mean age of the groups: T1DM, } \\
53.2 \pm 15.5 \text { years; T2DM, } 58.7 \pm 8 \\
\text { years; controls, } 50.3 \pm 14.8 \text { years) } \\
\text { A subset of } 23 \text { patients with diabetes } \\
\text { received CoQ10 orally for } 12 \text { weeks } \\
\text { (100 mg twice daily). }\end{array}$ & $\begin{array}{l}\text { AMPs and NK cells in diabetes } \\
\text { patients and the influence of CoQ10 } \\
\text { on these immune components in the } \\
\text { diabetic patients have } \\
\text { been investigated. }\end{array}$ & $\begin{array}{l}\text { Supplementation with CoQ10 } \\
\text { improved NK cell activity and } \\
\text { reduced hBD2 expression in T1DM } \\
\text { patients. This suggests that the } \\
\text { anti-oxidant CoQ10 also targets the } \\
\text { immune system and especially } \\
\text { improves T1DM-induced disorders. }\end{array}$ & Brauner et al., 2014 [59] \\
\hline
\end{tabular}


Table 1. Cont

\begin{tabular}{|c|c|c|c|c|c|}
\hline $\begin{array}{c}\begin{array}{c}\text { Exogenous Antioxidant } \\
\text { (Compound) }\end{array} \\
\text { (Con }\end{array}$ & Study Design & Study Protocol & Proncipal Endpoint & Observed Effect (Outcome) & Reference \\
\hline \multirow[t]{2}{*}{ Fish oil/primrose oil } & $\begin{array}{l}\text { Prospective, randomized } \\
\text { controlled trial }\end{array}$ & $\begin{array}{l}60 \text { postmenopausal, female patients } \\
\text { (mean age } 63.1 \pm 9.6 \text { years) with } \\
\text { rheumathoid arthritis (RA) were } \\
\text { recruited and divided into } \\
\text { three groups: group I } \\
\text { control group }(n=20 \text { ) only their } \\
\text { strikethrough rheumatologic therapy; } \\
\text { group II }(n=20 \text { ) taking, daily after } \\
\text { meals, five gel capsules of Omega- } 3 \\
\text { Cardio (containing } 1000 \mathrm{mg} \text { of } \\
\text { concentrated fish oil with } 300 \mathrm{mg} \text { of } \\
\text { docosahexaenoic acid (DHA), } 200 \mathrm{mg} \\
\text { EPA } 100 \mathrm{mg} \text { of other omega- } 3 \text { fatty } \\
\text { acids) in a period of } 3 \text { months with a } \\
\text { regular rheumatologic therapy, group } \\
\text { III }(n=20) \text { taking, daily after meals, } \\
\text { two gel capsules of Omega-3 Cardio } \\
\text { and two gel capsules of evening } \\
\text { primrose oil (containing } 1300 \mathrm{mg} \text { of } \\
\text { evening primrose oil with } 949 \mathrm{mg} \text { of } \\
\text { linoleic acid and } 117 \mathrm{mg} \text { of gamma } \\
\text { linolenic acid (GLA)) in a period of } \\
3 \text { months with a regular } \\
\text { rheumatologic therapy }\end{array}$ & $\begin{array}{l}\text { The following oxidative stress } \\
\text { markers have been evaluated: index } \\
\text { of lipid peroxidation (thiobarbituric } \\
\text { acid-reactive substances (TBARS)), } \\
\text { hydrogen peroxide (H2O2), } \\
\text { superoxide anion radical (O2 (-)), } \\
\text { nitric oxide (NO), superoxide } \\
\text { dismutase activity (SOD), catalase } \\
\text { activity (CAT), and glutathione levels } \\
\text { (GSH) in erythrocytes. }\end{array}$ & $\begin{array}{l}\text { No statistically significant changes } \\
\text { for any of the oxidative stress } \\
\text { parameters have been detected in } \\
\text { group I. In group II, levels of TBARS, } \\
\text { NO2 (-), and GSH were increased, } \\
\text { while levels of H2O2 decreased. } \\
\text { Increased values of TBARS, NO2 (-), } \\
\text { and SOD were found in group III. }\end{array}$ & $\begin{array}{c}\text { Vasiljevic et al., } 2016 \\
\text { [60] }\end{array}$ \\
\hline & $\begin{array}{l}\text { A } 6 \text { month single center, randomized, } \\
\text { single-blind (patient unaware of } \\
\text { treatment group), placebo-controlled, } \\
\text { parallelgroup pilot study. }\end{array}$ & $\begin{array}{l}50 \text { patients affected by Systemic } \\
\text { Lupus Erithematosus (SLE) (age } \\
\text { range } 18-64 \text { years) recruited in } \\
\text { outpatient clinics were randomized } \\
\text { 1:1 to fish oil supplementation or } \\
\text { olive oil placebo. ( } 6 \text { capsules/day } \\
\text { equaling } 2.25 \mathrm{~g} \text { EPA and } 2.25 \mathrm{~g} \text { DHA) } \\
\text { or placebo ( } 6 \text { capsules/day purified } \\
\text { [refined, not extra-virgin] olive oil } \\
\text { Metagenics) in addition to their } \\
\text { background therapies, for } 6 \text { months. }\end{array}$ & $\begin{array}{l}\text { RAND Short Form-36 (RAND SF-36), } \\
\text { Fatigue Severity Scale (FSS), SLE } \\
\text { Disease Activity Index (SLEDAI), and } \\
\text { Physician Global Assessment (PGA) } \\
\text { were evaluated. }\end{array}$ & $\begin{array}{l}\text { PGA swas ignificantly improved in } \\
\text { the fish oil group compared with the } \\
\text { placebo group }(p=0.015) \text {. The RAND } \\
\text { SF-36 Energy / fatigue and Emotional } \\
\text { well-being scores demonstrated } \\
\text { improvement trends }(p=0.092 \\
\text { and 0.070). } \\
\text { No clear difference was seen in FSS } \\
\text { and SLEDAI }(p=0.350 \text { and } p=0.417) \text {. } \\
\text { Erythrocyte sedimentation rate and } \\
\text { serum IL-12 were reduced ( } p=0.008 \\
\text { and } p=0.058) \text { while serum IL-13 was } \\
\text { increased by fish oil supplementation } \\
(p=0.033) \text {. }\end{array}$ & $\begin{array}{c}\text { Arriens et al., } 2015 \\
\text { [61] }\end{array}$ \\
\hline
\end{tabular}


Table 1. Cont

\begin{tabular}{|c|c|c|c|c|c|}
\hline $\begin{array}{c}\begin{array}{c}\text { Exogenous Antioxidant } \\
\text { (Compound) }\end{array} \\
\text { (a) }\end{array}$ & Study Design & Study Protocol & Proncipal Endpoint & Observed Effect (Outcome) & Reference \\
\hline \multirow[b]{2}{*}{ Melatonin } & & $\begin{array}{l}\text { Patients affected by Multiple sclerosis } \\
\text { (MS) ( } n=28 \text { ) before and after } 10 \\
\text { exposures of whole body cryotherapy } \\
\text { (WBCT; }-120 \text { degrees C } / 3 \mathrm{~min} / \text { day. } \\
16 \mathrm{MS} \text { patients during } 10 \text { exposures } \\
\text { of WBCT additionally were } \\
\text { supplemented by } 10 \mathrm{mg} \text { of melatonin. }\end{array}$ & $\begin{array}{l}\text { Total antioxidative status (TAS) in } \\
\text { plasma and activity of superoxide } \\
\text { dismutase (SOD) and catalase (CAT) } \\
\text { in erythrocytes of MS patients }\end{array}$ & $\begin{array}{l}\text { TAS level in plasma as well as } \\
\text { supplemented with melatonin and } \\
\text { non-supplemented MS patients was } \\
\text { observed after } 10 \text { exposures of WBCT. } \\
\text { Melatonin statistically significant } \\
\text { increased activity of SOD and CAT in } \\
\text { erythrocytes of MS patients treated } \\
\text { with WBCT. }\end{array}$ & Miller et al., 2011 [62] \\
\hline & Prospective study & $\begin{array}{l}102 \text { patients affected by Multiple } \\
\text { sclerosis (MS) and } 15 \text { healthy controls } \\
\text { (mean age } 36.45 \pm 8.16 \text { years) were } \\
\text { enrolled. Patients were divided into } \\
\text { groups according to different } \\
\text { immunomodifying therapies: } \mathrm{A} \\
\text { (interferons beta 1a, mean age } \\
41.22 \pm 7.1 \text { ); } \mathrm{B} \text { (interferons beta } 1 \mathrm{~b}, \\
\text { mean age } 39.48 \pm 9.42 \text { ), } \mathrm{G} \text { (glatiramer } \\
\text { acetate, mean age } 38.95 \pm 10.76 \text { ); } \mathrm{Mx} \\
\text { (mitoxantrone, mean age } \\
55.74 \pm 6.21 \text { ) and } \mathrm{P} \\
\text { (immunomodifying pre-treatment, } \\
\text { mean age } 37.33 \pm 9.23 \text { ); } \mathrm{R} \text { (relapse } \\
\text { gropup, mean age } 14.90 \pm 7.13 \text { ). } \\
\text { MS patients were supplemented with } \\
\text { melatonin ( } 5 \text { mg daily) for } 3 \text { months. }\end{array}$ & $\begin{array}{l}\text { Serum ceruloplasmin concentrations, } \\
\text { Expanded disability status scale score } \\
\text { (EDSS), brain magnetic resonance } \\
\text { imaging, serum C-reactive protein } \\
\text { level, and white blood cell count } \\
\text { were examined. }\end{array}$ & $\begin{array}{l}\text { Significantly increased levels of } \\
\text { ceruloplasmin in MS patients was } \\
\text { detected ( } p=0.0048) \text {. No differences } \\
\text { in ceruloplasmin concentrations } \\
\text { between the relapse group and } \\
\text { controls were observed. In A and G } \\
\text { groups, ceruloplasmin levels before } \\
\text { and after melatonin were similar to } \\
\text { levels in controls. In group B, } \\
\text { ceruloplasmin concentration was } \\
\text { significantly higher vs. control and } \\
\text { relapse groups. After } 3 \text { months of } \\
\text { melatonin administration in group B } \\
\text { patients, the levels of ceruloplasmin } \\
\text { decreased significantly ( } p=0.012) \text {. } \\
\text { No significant changes were observed } \\
\text { between controls, pretreated group, } \\
\text { and relapse group, and after } \\
\text { melatonin treatment in the group G. } \\
\text { after melatonin administration in the } \\
\text { Mx patient group, was observed a } \\
\text { ceruloplasmin levels decrease, but } \\
\text { not statistically significant. }\end{array}$ & Adamczyk-Sowa et al., 2016 [63] \\
\hline Probiotics & $\begin{array}{l}\text { A Randomized Double-Blind } \\
\text { Clinical Trial }\end{array}$ & $\begin{array}{l}46 \text { patients with Rheumatoid arthritis } \\
\text { (RA) were assigned to one of two } \\
\text { groups; patients in the probiotic } \\
\text { group ( } 41.14 \pm 12.65 \text { ) received a daily } \\
\text { capsule containing } 10^{8} \text { colony } \\
\text { forming units (CFUs) of Lactobacillus } \\
\text { casei } 01 \text { (L. casei 01), and placebo } \\
\text { group ( } 44.29 \pm 9.77) \text { took identical } \\
\text { capsules containing maltodextri for } \\
8 \text { weeks. }\end{array}$ & $\begin{array}{l}\text { Anxiety, physical activity levels, and } \\
\text { dietary intakes were assessed. } \\
\text { Anthropometric parameters, serum } \\
\text { malondialdehyde (MDA), total } \\
\text { antioxidant capacity (TAC), } \\
\text { erythrocyte superoxide dismutase } \\
\text { (SOD), glutathione peroxidase (GPx), } \\
\text { and catalase (CAT) activities } \\
\text { were measured. }\end{array}$ & $\begin{array}{l}\text { No significant difference between the } \\
\text { two groups for anthropometric } \\
\text { parameters, physical activity, anxiety } \\
\text { levels, or dietary intakes, throughout } \\
\text { the course of the study were detected. } \\
\text { No significant within- and } \\
\text { between-group differences were } \\
\text { observed for MDA, TAC, or CAT. } \\
\text { SOD activity decreased only in the } \\
\text { probiotic group and GPx activity } \\
\text { decreased in both study groups } \\
(p<0.05) \text {; no significant } \\
\text { between-group difference was found } \\
\text { for these enzymes activities at the } \\
\text { end of the study }(p>0.05) \text {. }\end{array}$ & Vaghef-Mehrabany et al., 2016 [64] \\
\hline
\end{tabular}


Table 1. Cont

Exogenous Antioxidant (Compound)
Study Desig
Proncipal Endpoin

60 patients affected by Multiple sclerosis (MS). Participants were randomly allocated into two groups to receive either a probiotic capsul $(n=30$; mean age $33.8 \pm 8.9$ ) or

Probiotics Randomized double-blind trolled clinical tria (nean a $34.4 \pm 9$ ) f 12 w mean age $34.4 \pm 9.2$ ) for 12 weeks Lactobacillus acidophilus, Lactobacill
casei, Bifidobacterium bifidum and Lactobacillus fermentum (each $\left.2 \times 10^{9} \mathrm{CFU} / \mathrm{g}\right)$.
Expanded disability status scale (EDSS) scoring, parameters of menta health and metabolic indicators were recorded at the baseline and 12 week fter the intervention.
44 patients (age range: $18-55$ years) with Rheumatoid arthritis were randomly divided into 2 groups (intervention and control). Patien consumed $200 \mathrm{mg} /$ day sesamin supplement and placebo in the intervention and control group respectively, for 6 weeks.
Anthropometric indices and blood pressure were assessed. Serum concentrations of lipid profile, malondialdehyde (MDA), and total antioxidant capacity (TAC) were also determined.
30 children (age range 8 to 17 years) suffering from type 1 diabetes. In the Vaccinium myrtillu
Placebo controlled trial first two months patients were given a placebo. In the next two months the dietary supplement was

administered $3 \times 1$
comprimates/day, before meals
Glycemia values (measured in the insuling, before the first dose of (HbA1C) C petion changes in antioxidant anyme activity after two months of treatment with the dietary supplements were evaluated.

\section{Observed Effect (Outcome)}

Probiotic intake improved EDSS

$(p=0.001)$, beck depression inventor ( $p<0.001)$, general health

questionnaire $(p<0.001)$, depression

Changes in high-sensitivity

C-reactive protein $(p=0.01)$, plasma

hitric oxide metabolites $(\mathcal{p}=0.002)$

and malondialdehyde (MDA)

$(p=0.04)$ were also significantly

different compared to placebo group.

Moreover probiotic capsule

Kouchaki et al., 2017 [65]

significantly decreased serum insuli

$(p<0.001)$, homeostasis model of

resistance $(p=0.001)$, Beta cell

function $(p<0.001)$,

total-/HDL-cholesterol $(p=0.02)$.

Quantitative insulin sensitivity chec

inde, $(p<0.001)$ and HDL-cholestero vels $(p=0.02)$, were also

Sesamin supplementation

gnificantly decreased serum levels TAC and high-density lipoprotein

cholesterol levels in patients with $R A$

$(p=0.020$ and $p=0.007$, respectively)

In the sesamin group, the mean of

weight, body mass index

waist-to-hip ratio, body fat, systolic

blood pressure, and the concentration

of triglycerides, total cholesterol, and

low-density lipoprotein cholestero

were also significantly decreased

compared to baseline values $(p$

between the 2 groups was not

statistically significant in this regat $(p>0.05)$

Two months of supplementation with

blueberry (Vaccinium myrtillus)

antioxidant response in young type 1

diabetic patients. SOD and GPX

augmented the antioxidant response

as well. The phytotherapics had

hypoglycemic results too, with

consequent need for

insulin-treatment calibration.
Helli et al., 2016 [66]

Nemes-Nagy et al., 2008 [67] 
Table 1. Cont.

\begin{tabular}{|c|c|c|c|c|c|}
\hline $\begin{array}{l}\text { Exogenous Antioxidant } \\
\text { (Compound) }\end{array}$ & Study Design & Study Protocol & Proncipal Endpoint & Observed Effect (Outcome) & Reference \\
\hline Vitamin C & $\begin{array}{l}\text { Randomized, double blind, placebo } \\
\text { controlled pilot study }\end{array}$ & $\begin{array}{l}39 \text { Patients affected by Systemic } \\
\text { Lupus Erithematosus (SLE) (mean } \\
\text { age was } 46 \pm 9 \text { years) were } \\
\text { randomized to receive either } \\
\text { vitamins }(n=20 ; \text { mean age } \\
44 \pm 6 \text { years) } 500 \mathrm{mg} \text { vitamin } C \text { and } \\
800 \mathrm{IU} \text { vitamin } \mathrm{E} \text { daily) or placebo } \\
\text { ( } n=19 ; \text { mean age } 48 \pm 11 \text { years) for } \\
12 \text { weeks. }\end{array}$ & $\begin{array}{l}\text { Malondialdehyde (MDA) and } \\
\text { allantoin were evaluated. Erythrocyte } \\
\text { superoxide dismutase and } \\
\text { glutathione peroxidase, plasma total } \\
\text { antioxidant power (as FRAP value), } \\
\text { and ascorbic acid and vitamin E } \\
\text { concentrations were also measured. } \\
\text { Endothelial function was assessed by } \\
\text { flow-mediated dilatation (FMD) of } \\
\text { the brachial artery and plasma } \\
\text { concentration of von Willebrand } \\
\text { factor (vWF) and plasminogen } \\
\text { activator inhibitor type } 1 \text { (PAI-1). }\end{array}$ & $\begin{array}{l}\text { Plasma ascorbic acid and } \\
\alpha \text {-tocopherol concentrations were } \\
\text { significantly ( } p<0.05) \text { increased only } \\
\text { in the vitamin-treated group, } \\
\text { associated with a significant decrease } \\
(p<0.05) \text { in plasma MDA. Other } \\
\text { oxidative stress markers and } \\
\text { antioxidant levels remained } \\
\text { unchanged in both groups. FMD and } \\
\text { vWF and PAI-1 levels remained } \\
\text { unchanged in both groups. }\end{array}$ & Tam et al., 2005 [68] \\
\hline Vitamin D & $\begin{array}{l}\text { randomized, double blinded, } \\
\text { placebo-controlled clinical trial }\end{array}$ & $\begin{array}{l}53 \text { Patients affected by Multiple } \\
\text { sclerosis (MS), were recruited and } \\
\text { divided into } 2 \text { groups to receive } \\
\text { either } 2 \omega-3 \text { fatty acid capsules daily } \\
\text { (containing } 500 \mathrm{mg} \text { DHA and } 106 \mathrm{mg} \\
\text { EPA) plus vitamin D3 as } \\
\text { cholecalciferol supplements } \\
\text { (50,000 IU /biweekly) }(n=26 \text {; mean } \\
\text { age } 33.3 \pm 6.5 \text { years) or sunflower oil } \\
\text { capsules (placebo, } n=27 \text {; mean age } \\
35.2 \pm 9.2 \text { years) for } 12 \text { weeks. }\end{array}$ & $\begin{array}{l}\text { The primary outcomes of the study } \\
\text { included Expanded disability status } \\
\text { scale (EDSS) score and inflammatory } \\
\text { markers. Biomarkers of oxidative } \\
\text { stress and metabolic profiles were the } \\
\text { secondary outcomes of the study. }\end{array}$ & $\begin{array}{l}\text { Coadministration of } \omega-3 \text { fatty acid } \\
\text { and vitamin D3, for } 12 \text { wk, } \\
\text { significantly decreased EDSS score } \\
(p=0.01) \text { in patients with MS. Serum } \\
\text { hs-CRP }(p<0.001), \text { plasma TAC } \\
(p=0.02), \text { GSH }(p=0.007) \text {, and MDA } \\
(p<0.001) \text { improved significantly in } \\
\text { the supplemented group, compared } \\
\text { with the placebo group. } \\
\text { A significant reduction in serum } \\
\text { insulin }(p=0.008), \text { HOMA-IR } \\
(p=0.01) \text {, and total//HDL-cholesterol } \\
(p=0.04) \text { was also reported. } \\
\text { A significant increase in QUICKI } \\
(p=0.008) \text { and serum } \\
\text { HDL-cholesterol concentrations } \\
(p=0.009) \text { compared with the } \\
\text { placebo was also reported. }\end{array}$ & Kouchaki et al., 2018 [69] \\
\hline \multirow[t]{2}{*}{ Vitamin E } & $\begin{array}{l}\text { Double-blind, placebo controlled } \\
\text { clinical trial }\end{array}$ & $\begin{array}{l}\text { Diabetic patients }(n=29 ; \text { mean age } \\
12.7 \pm 0.8 \text { years) and healthy control } \\
(n=21 ; \text { mean age } 10.9 \pm 0.9) \text { were } \\
\text { recruited for the study. Diabetic } \\
\text { patients were supplemented with } \\
\text { DL-a-tocopherol (vitamin E) capsule } \\
\text { (orally, } 100 \text { IU /day) or placebo for } \\
3 \text { months. Alternate diabetic patients } \\
\text { were assigned to vitamin E or placebo } \\
\text { during regular visits to the clinic. }\end{array}$ & $\begin{array}{l}\text { Platelet aggregability was assessed by } \\
\text { assay of the blood TxB2. } \\
\text { Plasma vitamin E and MDA } \\
\text { (malondialdehyd) levels } \\
\text { were assessed. }\end{array}$ & $\begin{array}{l}\text { Vitamin E supplementation lowered } \\
\text { MDA levels by } 30 \%(p<0.04) \text {, TxB2 } \\
\text { levels by } 51 \%(p<0.03) \text {, and } \\
\text { triglyceride levels by } 22 \%(p<0.04) \text { in } \\
\text { diabetic patients. }\end{array}$ & Jain et al., 1998 [70] \\
\hline & Placebo controlled trial & $\begin{array}{l}60 \text { diabetic patients were assigned to } \\
\text { receive Vitamin } \mathrm{E} \text { (a-tocopherol) } \\
900 \mathrm{mg} / \text { daily }(n=32, \text { mean age } \\
45.7 \pm 17) \text { or placebo }(n=28 ; \text { mean } \\
\text { age } 44.17 \pm 11.5) \text { for } 12 \text { weeks. }\end{array}$ & $\begin{array}{l}\text { DNA damage (based on extend of } \\
\text { DNA migration) }\end{array}$ & $\begin{array}{l}\text { Supplementation of Vitamin E } \\
\text { significantly decrease in DNA } \\
\text { migration in all } 32 \text { treated patients } \\
\text { compared with their mean cells with } \\
\text { migration before treatment }(p<0.05) \text {. }\end{array}$ & Sardas et al., 2001 [71] \\
\hline
\end{tabular}


Table 1. Cont

Exogenous Antioxidan
Study Design
Proncipal Endpoin

Ten young adults (mean age $18.87+/-2.91$ years) with T1DM and persistent microalbuminuria (MA) were recruited. The vitamin elastic gelatine (each capsule

Randomized, placebo-controlled,

acetatedissolved in 100 mg of edible vegetable oil. Placebo

capsules contained $500 \mathrm{mg}$ of soybean oil dissolved in the same $100 \mathrm{mg}$ of vehicle.

Treatment was administerd fo

12 months.
Evaluation of the effects of high-dose vitamin E supplementation on reducing both MA and oxidative stress in patients with type 1 diabetes mellitus and persistent MA. Determination of albumin excretion rate (AER) and HbA1c and oxidant/antioxidan tatus were performed.
40 children (20 Type 1 Diabetes and 20 healthy supplemented with $600 \mathrm{mg} /$ daily vitamin $\mathrm{E}$ for three months.
Oxidative stress parameters antioxidants, reduced glutathione (GSH), vitamin E and metabolic parameters were evaluated before and after the period of supplememtation

\section{Observed Effect (Outcome)}

No differences in terms of oxidan

between the two groups. This was

associated with no significantly

different urinary VEGF and TGF-beta

levels. After 6 months, no significant

differences in AER were observed

between the two groups $(p=0.59)$.

However, plasma and LDL-vitamin $\mathrm{E}$ content were significantly higher in the vitamin $E$ group compared to $p=0.004$, respectively). This was $p=0.004$, respectively). This was lag phase $(p=0.002)$ and lower MDA $(p=0.049)$. However, no statistically significant differences were detected in terms of VEGF and TGF-beta urinary levels.

Vitamin E supplementation caused

significant decrease in MDA level

levels in diabetic patients No

significant changes were observed in

metabolic parameters in Type

Diabetes Mellitus patients after
vitamin E supplementation $(p>0.05)$

Nine children and adolescents (age range 8-15 years; mean age Mean ag was $12.9 \pm 0.9 \mathrm{yr}$ ) with T1DM were included in this study.

Open-label antioxidant

supplementation was given for six weeks.The doses were chosen to be Cand 400 IU of vitamin E per day in a $75 \mathrm{~kg}$ adult.

(<30 kg; Vit C 250mg; Vit E100 IU); (30-60 kg; Vit C 500mg; Vit E 200 IU); ( $>60$ kg; Vit C 750mg; Vit E 300 IU).
Endothelial function and plasma endothelial risk antioxidant capacis inflammatory markers (CRP and IL6) were evaluated. Effect on endothelial colony forming cells (ECFCs: CD34+ CD133+
No differences were seen in the

to combined vitamin $\mathrm{C}$ and $\mathrm{E}$ supplementation. No differences were observed in hsCRP, total plasma antioxidant capacity (TAOC)

adiponectin, or endothelial

progenitor cells before or after
Giannini et al., 2007 [72]

Gupta et al., 2011 [73]

Cazeau et al., 2016 [74] 
Table 2. Pre-clinical study carried out with selected compounds in experimental models of autoimmune diseases.

Exogenous Compound

Flavonoids
Male Sprague-Dawley rats

Intragastric gavage

\section{Experimental Model/Dosage}

hirty-six rats were randomly allocated to 2 groups. 1 group was randomly chosen to be a diabetic group $\mathrm{mg} / \mathrm{kg}$ body weight in $0.1 \mathrm{~mol} / \mathrm{L}$ sodium citrate buffer). Three days after diabetes induction, each group was randomly divided into 3 subgroups 6 animals each ([1] control, [2] 1\% cliniptilolite (CLN)/food, [3] $1 \%$ nano sized CLN (NCLN)/food). Anim powdered CLN or NCLN and a diet for 4 consecutive weeks.

Eighty rats were randomly divided into 8 groups of 10 rats each. Groups and 2 were fed with the control diet, roups 3 and 4 with $4.0 \%$ Stevia rebaudiana leaves powder incorporated reups 5 and 6 with equivalent of polyphenols extract (through force feeding); groups 7 and 8 with equivalent amount of fiber extracted from $4 \mathrm{~g}$ of Stevia rebaudiana leaves powder respectively for 5 weeks.

\section{Quercetin and allopurinol were}

suspended in water and administere via intragastric gavage $\left(1 \mathrm{~mL} \cdot 100 \mathrm{~g}^{-1}\right.$ bor 4 . once daily for 7 weeks.

Cells were cultured in merformed.

containing low-glucose DMEM (5.5 mM) and $10 \%$ FBS. Cells were maintained at low glucose (.5 $\mathrm{mM}$, as control) or hith glucose (30 10-20 the prese or allopurinol or $20 \mu \mathrm{M}$ of the caspase-1-specific inhibito (Ac-Tyr-Val-AlaAsp-chloromethylketone) for 24,48 or $72 \mathrm{~h}$

\section{Observed Effects}

Blood glucose and malondialdehyde

were significantly elevated. No

statistically significant changes in

peroxidase or total antioxidant capacity

diabetic rats treated with NCLN, blood

glucose decreased to near normal

levels (12.4 vs. $27.5 \mathrm{mmol} / \mathrm{L})$. No
significant changes were found in the

other groups. None of the oxidative

stress indices showed significant

changes in either the treated or

untreated rats.

Results showed a reduction of blood

of insulin level in the stevia whole

leaves powder and extracted

polyphenols fed rats compared to

control diabetic group. Its feeding also

reduced the MDA concentration in

status through antioxidant enzymes.

Clucose tolerance and insulin

sensitivity were improved by

their feeding.

Moreover in the Stevia rebaudiana leave

and extracted polyphenol fed group

kidney damage has been shown.

Quercetin and allopurinol significantly

inhibited the TXNIP overexpression

activation of NOD-like receptor 3

(NLRP3) inflammasome,

up-regulation of sterol regulatory

SREBP-2, faty P

$X$ receptor $\alpha$, well as elevation live

ROS and IL- $1 \beta$ in diabetic rat liver.

These effects were confirmed in

hepatocytes in vitro and it was further

shown that TXNIP down-regulation

contributed to the suppression of

inflammation and changes in PPÁR

and SREBPs.
Hossein et al., $2018[75$

Shivanna et al, 2013

(1)


Table 2. Cont.

Exogenous Compound
Species

Intragastric gavage

Male Wistar rats
Experimental Model/Dosage Diabetic induced animals receive daily, water (placebo groups) or

1 /day; FSP-supplemented (FSP) for 3 weeks. FSP is a soluble powder containing $29 \%$ alpha-GOSs

alpha-linked galactooligosaccarides) and $0.5 \%$ soy isoflavones (daidzein and genistein).

Diabetic control group (DM) was fed a common semipurified diet, and

which

which provided $25 \%$ of the total amin

acid nitrogen for $8 \mathrm{wk}$

Diabetes was induced by an

intraperitoneal injection of

nicotinamide (NA) $150 \mathrm{mg} / \mathrm{k}$

followed by STZ.

Diabetic rats were treated with aqueous lichen extracts (250 and 500

were obtained from $C$ is. The extracts furfuracea lichen species

\section{Observed Effects}

Reference

SP supplementation in diabetic animals normalized the CML and nd tended to increase Mn-SOD expression. IL-1b, IL-6 and uric aci were markedly decreased by FSP supplementation.

Gene expressions of transformin growth factor-b1 and interleukin-17A did not differ in blood mononuclear cells among the three groups.

Expressions of interleukin-6,
interleukin-23, monocyte chemotactic prenterin-23, monocyte chemo protein-1, and the receptor of the

were higher in blood mononuclear cells and the ratio of reduced to oxidized glutathione was lower in erythrocytes in the DM group than in the normal control group. mRNA expressions of these genes were lower, whereas the glutathione was higher in the DM-Cln group than in the DM group.

Blood glucose and insulin levels were not affected by Lichex extrac

of antioxidant enzymes at both level ( 250 and $500 \mathrm{mg} / \mathrm{kg}$ ) but the best result was observed at the doses of $C$.

SOD and CAT activities were not

significant in induced diabetic groups and oxidative stress did not return to the control levels, moreover the improve diabesinduced pancreatic damage. 
Table 2. Cont.

Exogenous Compound

Route of Administration

Olive leaf powder

Male mice

Origanum vulgareOriganum vulgare $L$.
ssp. hirtum (Greek oregano) leaf extract rich in biophenols.

C57BL/ 6 mice 5 groups (C) control; (D) diabetes; V ery low dose of olive leaf powder
(VLOL, diabetes $+0.3 \%$ olive leaf

powder); low dose of olive leaf powder
(LOL diabetes $+0.6 \%$ olive leaf ose of olive lea powder (HOL, diabetes $+3 \%$ olive lea powder). Animals received the

Methanolic estrac (MOE) or extrac (AOE) were administered for injections at a dose of $5 \mathrm{mg} / \mathrm{kg}$ per starting from the day of diabetes induction (prophylactic' regimen) or starting $1 \mathrm{~d}$ after the last streptozotocin injection (early herapeutic). Rosmarinic acid was administered intraperitoneally for (

Animals were distributed into four (CTLK): diatetic (DM) and diabetic Kefir (DMK). Starting on the 5 th day of iabetes, Kefir was administered by daily gavage at a dose of $1.8 \mathrm{~mL} / \mathrm{d}$ ay for 8 weeks.

Animals were divided into four groups: control group, group supplemented wi induce diabetes

group: treated with supplemented with zinc.

The experiments were carried out over 6 -weeks period starting 3 days after STZ injection.

\section{Observed Effects}

Reference

SOD, CAT and GPx were increased
the VLOL and LOL groups. Nitri

oxide levels decos ged in ted VLOL

axide levels decreased in the VLOL

group. mRNA expression levels of

iNOS were significantly decreased in

the VLOL and HOL groups, and IFN- $\gamma$

levels were significantly decreased in

the liver of the VLOL, LOL, and HOL

group. IL-17 levels were significanty

decreased in the VLOL and HOL

groups. Th1 and Th17 cytokine levels

were increased in the D group but

decreased in all the experimental

groups. Th2 cytokine levels wer

increased in all olive

with

MOE reduced diabetes incidence and

pddition MOE treasuris

attenuated the pro-inflammatory

response mediated by Thelper 17 cells

and enhanced anti-inflammatory $T$

helper 2 and $\mathrm{T}$ regulatory cells through

the impact on specific signalling

pathways and transcription factors,

preserved $\beta$-cells from in vitro

Rosmarinic acid, kasibe 3.

protection from diabetes induction.

DMK rats showed a significan

duction of iNOS expression.

Moreover, the DMK group presented a

significant reduction of glycogen

accumulation within the renal tubs.

Zinc supplementation showed a

protective effect against diabetic

damage of kidney tissue through

stimulation of metallothionein
synthesis and regulation of the

synthesis and re

The activity of glutathione peroxidase

did not change in any of the four

groups.
Park et al, 2013 [81]

Vujicic et al., 2015 


\subsection{Rheumatoid Arthritis}

Rheumatoid arthritis (RA) is a chronic autoimmune disease characterized by systemic inflammation; patients often present symptoms like swelling, tenderness, and gradual permanent damage to joints. These symptoms lead to functional disability and to an augmented mortality. Unfortunately, RA is pretty common in immune-related disorders affecting from the $0.5 \%$ to $1 \%$ of the population, occurring 3 times more frequently in women [85]. Its pathogenesis is still an object of study, but T and B cells as well as macrophages and synoviocytes are key players provoking a detrimental cascade based on cytokine release, tissue damage, and ROS generation. Local and general inflammation are natural consequences [86].

Many studies have evaluated the efficacy of alpha-lipoic acid (ALA) in RA patients [53]. In particular, ALA is a potent antioxidant. In this study, ALA did not significantly change the serum levels of pro-inflammatory biomarkers, such as tumor necrosis factor-alpha (TNF- $\alpha$ ), interleukin-6 (IL-6), fundamental cytokines implicated in the pathogenesis of RA, C-reactive protein (hs-CRP), and matrix metalloproteinases (MMP-3). The authors did not find a statistically significant correlation with these cytokines and development of AR; therefore, the levels of ROS before the analysis were not significant [53].

One of the last frontiers in terms of supportive therapies is altering gut microbiota. Some authors tested the hypothesis that restoring altered microbiota in RA patients could be useful for controlling cellular damage, oxidative stress, and inflammation. Unfortunately, no beneficial effects of $L$. casei supplementation on the oxidative status of patients with RA were observed [64]. However, some animal studies are in conflict with this result [87] and not all of the results were negative in the human RA research. In fact, probiotic yogurt intake augmented some endogenous antioxidants, although not enough to modify oxidative stress parameters [64].

Sesamin supplements exhibited a protective effect on the modulation of heart and metabolic-related risk factors in women affected by RA. A dose of $200 \mathrm{mg}$ per day for a period of 6 weeks significantly ameliorated some parameters; anthropometric indices, lipid profile, blood pressure, and oxidative stress markers were some of those. Sesamin, which is low-cost and free of side effects, is a valid supplement for the prevention of cardiovascular accidents in RA and in patients with similar risk factors [66].

A study conducted in Iran evaluated the effects of the intake of Coenzyme Q10 (CoQ10) on plasmatic levels of oxidative stress and inflammatory markers such as malondialdehyde (MDA), total antioxidant capacity (TAC), IL-6, and TNF-a in RA patients. According to the results, CoQ10 intake for 8 weeks lead to a massive reduction of blood MDA. Moreover, the capability of CoQ10 of interfering with inflammatory mediators could be due to its efficiency in blocking the nuclear factor kappa B (NF-kB) cascade. Plasmatic TAC and IL-6 were not affected [56].

Fish oil, concentrated fish oil, and their combination with evening primrose oil were tested for their antioxidant activity in a 3 month study of patients affected by RA. The concentrated fish oil group displayed augmented levels of thiobarbituric acid reactive substances (TBARS) and nitrogen dioxide $\left(\mathrm{NO}_{2}{ }^{-}\right)$in blood; in addition, $\mathrm{GSH}$ levels were augmented as well, with a reduction of plasmatic $\mathrm{H}_{2} \mathrm{O}_{2}$. Similar results were achieved using the concentrated fish oil combined with evening primrose oil. In addition, the last group had increased activity of SOD. These data confirmed the speculation of the authors regarding the antioxidant capacities of the described oils by ameliorating the endogenous antioxidant enzymes [60].

\subsection{Systemic Lupus Erythematosus}

Another important autoimmune disease is systemic lupus erythematosus (SLE). Its importance is due to its high mortality rate. SLE pathogenesis is still unclear. Genetics, environment, drugs, pregnancy, and infection are only part of the complex disease mosaic [88]. It is a multiorgan disorder: mucosa, joints, kidneys, lungs, hearts, and particularly nerve cells in the peripheral nervous system are particularly targeted [89]. Among the 
risk factors for SLE is oxidative stress. Due to its severity, studies have been conducted that evaluated the potential use of antioxidant drugs and integrators as treatments. SLE subjects were tested using either a placebo or vitamins $C$ and $E$ (500 $\mathrm{mg}$ vitamin $C$ and $800 \mathrm{IU}$ vitamin E daily) for 3 months. Oxidative stress was evaluated by dosing with malondialdehyde (MDA) and allantoin. Erythrocyte superoxide dismutase, glutathione peroxidase, and plasma total antioxidant power (as FRAP value) were the parameters considered for monitoring antioxidant capacities.

As a result, the treated group had an increase in ascorbic acid and alpha-tocopherol as well as a substantial decline of MDA. Lipid peroxidation diminished without interfering with endothelial function [68]. As demonstrated for RA, fish oil also showed its efficacy in SLE. Pro-inflammatory cytokines such as IFN-alpha, IFN-gamma, IL-10, IL-12, IL-13, IL-15, IL-17, IL-1beta, IL-1RA, IL-2, IL-2R, IL-4, IL-5, IL-6, IL-7, IL-8, IP-10/CXCL10, MCP1/CCL2, MIG/CXCL9, MIP-1alpha/CCL3, MIP-1beta/CCL4, RANTES/CCL5, TNF-alpha, and VEGF decreased significantly after fish oil intake [61].

\subsection{Multiple Sclerosis}

Multiple sclerosis (MS) is characterized by an inflammatory neurodegenerative condition of the central nervous system which is typical of young and adult female subjects; in a minor percentage of cases it affects men. As in other diseases, in MS oxidative stress also is thought to be a key player along with chronic inflammation [69].

Oxidative stress is an important factor for the pathogenesis of this ailment. Its part in MS is connected to accelerated production of a few types of ROS, mainly through macrophages as the main factors responsible for demyelination and axonal injuries. Both the demyelination and the inflammation processes are connected to producing ROS [90].

A significant increase of total antioxidative status (TAS) level in plasma was noted in MS patients undergoing whole-body cryotherapy (WBCT) treatment. This indicates that WBCT might be a therapy which suppresses oxidative stress in MS patients. WBCT is a relatively new method of treatment, and is more and more often used in neurological ailments due to its analgesic behavior, muscle tone relief, and antidepressant effect, increasing the efficiency of kinesiotherapy. In MS pathophysiology, oxidative stress plays a major role. This is why seeking antioxidative therapies is key for treating MS patients. This study determined the level TAS in plasma and the activity of superoxide dismutase (SOD) and catalase (CAT) in erythrocytes of MS patients after 10 exposures of WBCT. Additionally, some of MS patients undergoing WBCT were supplemented with melatonin [62]. In subjects affected by MS, CoQ10 dietary intake (500 mg/day) was effective in decreasing oxidative stress and increasing antioxidant systems and demonstrated reduced lipid peroxidation, augmented E vitamin disposal, and balanced NO-related signaling. A direct result of these effects was neuroprotection [57]. In another study, CoQ10 supplementation was also found to improve fatigue and depression in patients with MS [58].

According to Sowa et al., ceruloplasmin was high in novel diagnosed MS subjects. In addition, ceruloplasmin level was related to the diverse immunomodulatory treatments administrated. Mitoxantrone and interferon beta $1 \mathrm{~b}$ were linked to elevated ceruloplasmin levels. However, 12 weeks of melatonin intake ameliorated the protein levels in the control group. Ceruloplasmin was not connected to the phase of the disease. After treatment with interferon beta $1 \mathrm{~b}$ and glatiramer acetate, ceruloplasmin diminished [63].

Administration of probiotics for 3 months in MS patients improved the expanded disability status scale (EDSS), parameters of mental health, inflammatory factors, markers of insulin resistance, HDL-, total-/HDL-cholesterol, and MDA levels [65]. For the same time period, other authors treated MS subjects with $\omega-3$ fatty acid and vitamin D3 with positive outcomes on their disability score, inflammation and antioxidant capacity, and metabolic status. Other inflammatory parameters and oxidation markers were ameliorated. Among these were serum hs-CRP, plasma TAC, GSH, MDA, insulin metabolism, HDL-, and total/HDL-cholesterol [69]. 


\subsection{Diabetes Mellitus}

Diabetes mellitus is one of the most threatening diseases of the modern world due to its diffusion and short- and long-term consequences. It is characterized by a complete or partial lack of insulin secretion and/or insulin metabolism which results in chronic hyperglycemia. Ocular, renal, and cardiovascular pathologies are only some of the longterm effects primarily due to hyperglycemia. Research over the last few decades proposes chronic hyperglycemia as a principal causative agent of ROS production [75].

In particular, DM-1 is determined by gradual and irreversible immune-associated damage of insulin-producing pancreatic $\beta$ cells. Hyperaggregability of platelets was intimately linked to lipid peroxidation products, like MDA in DM-1. Vitamin E (100 IU/day) was effective in reducing blood markers of hyperaggregability and lipid peroxidation [70].

Impaired endothelial vasodilator function (EVF) is related to low density lipoprotein (LDL) and vitamin E content (VEC) in patients with type $1 \mathrm{DM}$, highlighting the importance of oxidative stress in the disease. Vitamin $\mathrm{E}$ intake ameliorated vascular parameters in young DM-1 patients. This result was mostly connected to better LDL, VEC, and diminished oxidative vulnerability to LDL [91].

ROS and vessel damage are often linked in DM patients. A direct consequence is DNA damage in peripheral blood lymphocytes, as demonstrated by the comet assay. Vitamin $\mathrm{E}$ administration for 3 months improved the antioxidative response [71].

Wold et al. suggested the occurrence of augmented oxidative stress in diabetes due to the clear alterations in coenzymes Q9 and Q10 levels. IGF-1 supplementation abolished this effect, except for Q9 levels in the liver. The authors speculated that IGF-I could be useful in avoiding hyperglycemia-induced organ damage and oxidative stress in DM patients with comorbidities [27].

High-dose vitamin E administration (1200 mg/day) reduced markers of oxidative stress and improved antioxidant defenses but unfortunately had no effect on improving microalbuminuria (MA) [72].

Phytotherapeutic substances were also studied. Many of them were known to have hypoglycemic effects and antioxidant capacities. Allium sativa, Ricinus communis, Securinega virosa, and Cassia auriculata were administrated by ancient populations. Two months of supplementation with blueberry (Vaccinium myrtillus) concentrate augmented the antioxidant response in young type 1 diabetic patients. SOD and GPx augmented the antioxidant response as well. The phytotherapics had hypoglycemic results also, with a consequent need for insulin-treatment calibration [67].

Tsai et al. noticed that a diet including glutamin (Gln) did not modify plasmatic glucose. The inflammatory infiltration was lower and the GSH/GSSG ratio was augmented. In particular, leukocyte adhesion molecules, organ nitrotyrosine concentrations, and liver neutrophil infiltration were affected by Gln intake [79].

Gupta et al. suggested that vitamin E ameliorated oxidative stress in DM-1 subjects. They speculated that it improves antioxidant defenses. MDA levels were higher in DM1 patients. The supplementation decreased MDA levels and augmented GSH [73].

A study was conducted on young adult males with uncomplicated type 1 diabetes to verify the effects of supplementation with 1 -arginine $(7 \mathrm{~g} /$ day $)$ on endothelial function and on markers of oxidative stress. The authors examined L-arginine actions in terms of vascular and antioxidant protection. Oxidative stress/damage markers, carbonyls, and thiobarbituric acid reactive substances (TBARS) were increased in DM patients and Larginine administration improved blood flow but did not influence the oxidative status [55].

Zinc supplementation was studied in an experimental animal model showing improved renal function in diabetic mice. It reduced the lipid peroxidation status in the kidney. As a consequence, the authors hypothesized that zinc supplementation could help moderate DM progression and effects. The diminution of $\mathrm{Zn}$ and $\mathrm{Zn}$-dependent antioxidant enzymes could be one of the main causes of DM oxidative damages. Zinc was also reported to induce metallothionein (MT) gene expression, boosting antioxidant performance [84]. 
Shivanna et al. showed the effects of Streptozotocin-induced diabetes. Powdered stevia leaves and the extracted polyphenols were potent boosters of plasmatic glucose metabolism, with a reduction of ALT and AST in diabetic rats. Their administration also affected MDA reduction and supported antioxidant defenses [76].

The role of the thioredoxin interacting protein (TXNIP) was also evaluated. It was found to have a role in the pathogenesis of nonalcoholic fatty liver disease (NAFLD) in diabetes. The results obtained through in vivo and in vitro studies have shown that quercetin and allopurinol suppress the activation of inflammasome 3 containing the pyrine domain (NLRP3) and reduce the levels of interleukin-1 (IL-1 $\beta$ ) by blocking overexpression of the hepatic protein interacts with the thioredoxin TXNIP and then modulates the expression of lipid metabolism genes in high glucose conditions. These data support the evidence that inhibition of hepatic TXNIP contributes to the alleviation of liver inflammation and lipid accumulation in type 1 diabetes. The effects on hepatic TXNIP caused by quercetin and allopurinol might have some implications for the avoidance of type 1 diabetes-associated non-alcoholic fatty liver disease (NAFLD) [77].

Regular intake of olive oil, has been associated with many health benefiting effects experienced by Mediterranean populations [92]. Administration of olive leaf powder has been shown to play a role in the suppression and production of proinflammatory mediators and NO-associated oxidative stress. Preventing hypoglycemia and augmenting enzyme antioxidants activities are examples of its effects. Olive leaf powders demonstrated diminishing kidney damage by reducing immune response, inflammation, and oxidative stress [81].

Probiotics proved their efficacy in DM treatment when Purano et al. tested Kefir, a probiotic fermented milk, on diabetic animals. The expression of inducible NO synthase (iNOS) was reduced in the kefir group, indicating improved glucose metabolism and a better antioxidant capacity [83].

Some authors evaluated the ability of CoQ10 to interfere with antimicrobial peptides and natural killer (NK) cells; in fact, these components are involved as causative agents of $\mathrm{DM}$ and its long-terms effects. These parameters were measured in diabetic patients after 3 months of CoQ10 administration. Plasmatic human cathelicidin antimicrobial peptide (CAMP) and human beta defensin 1 (hBD1), both antimicrobial peptides, were diminished in DM-1 subjects. CoQ10 did not affect them. The enzyme moderated the quantities of circulating hBD2 and stimulated modification of the subset distribution and activation markers in peripheral NK cells [59].

Isoflavones and alpha-galactooligosaccharides in soy exert antioxidant and antiinflammatory actions. Fermented soy permeate (FSP) diminished oxidative stress and inflammation in diabetic animals. FSP integration regulated levels of carboxymethylisine (CML) and antioxidant enzyme activity and augmented Mn-SOD. Other pro-inflammatory mediators were also reduced after the test [78].

The role of lichens as a new bio-resource for natural antioxidants was also evaluated. In particular, the effects of the lichen species Cetraria islandica and Pseudevernia furfuracae were tested in diabetic conditions. The results revealed that these lichen species could be used safely within a certain dose range. Furthermore, C. islandica extracts showed important results compared to the P. furfuracae extract for antioxidant capacity. However, the protective effects of the $C$. islandica extract were insufficient against diabetes-induced pancreatic damage through the formation of oxidative stress. In conclusion, the use of C. islandica could serve as a prompt intervention in the reduction of the risk of type 1 diabetes [80].

The therapeutic potential of Origanum vulgare L. ssp. hirtum leaf extract (Greek oregano) was also evaluated. Rich in biophenols, methanolic oregano extract (MOE) for the treatment of T1DM was examined. The extract reduced the disease occurrence and conserved normal insulin release. Oregano was effective in reducing ROS and NOS. Once more, the antioxidant capacity occurred side-by-side with the anti-inflammatory action. Th17, Th2, and Treg were fundamental in this process. Secondarily, MOE protected B-cells 
from in vitro apoptosis by blocking caspase-3. Lastly, rosmarinic acid, a main component in MOE, only demonstrated incomplete protection from diabetes induction. Thus, MOE prevented mice from diabetes spread [82].

There is a positive association between an antioxidant diet supplemented with alphalipoic acid and a decrease in endothelial dysfunction in pediatric patients with T1DM. This was demonstrated after dividing 71 children into three groups: those on an antioxidant diet + alpha-lipoic acid, those on an antioxidant diet + placebo, and controls. A substantial decrease in bolus insulin was observed. It was therefore assumed that alpha-lipoic acid has an antioxidant influence in pediatric diabetes patients by decreasing insulin [54].

It is well known that diabetic patients could have cardiovascular damage as a consequence of endothelial dysfunction caused by hyperglycemia which in turn provokes oxidative damage, sustaining inflammation. Vitamins $\mathrm{C}$ and E might ameliorate endothelial function (EF), but some results were contrasting [74].

Hossein Nia et al. examined if clinoptilolite and nano-sized clinoptilolite decrease hyperglycemia and oxidative stress in animals affected by DM. They observed that nanosized clinoptilolite had a hypoglycemic effect with no substantial influence on the markers of oxidative stress [75].

\section{Antioxidants in Autoimmune Diseases}

Reactive oxygen species (ROS) are commonly known as "oxidants". They have the ability to act in their initial form or to react with other molecules, leading to a generation of other ROS. They can interact with several compounds such as lipids, proteins, and DNA. Augmented levels of ROS compromise normal life-processes in the human body, contributing to the pathogenesis of several diseases. An oxidant-antioxidant disequilibrium is detrimental for lipids, proteins, and DNA. Lipid peroxidation can irreversibly compromise cell membrane integrity, affecting its fluidity. This process also diminishes hydrophobicity of the cell membrane and augments its permeability. The normal consequence of this impaired structure is a fracture. On the other hand, oxidation of proteins also compromises their structure. The formation of additional bonds results in altered or destroyed enzyme functionality [3]. The hostile nature of ROS contributes to the promotion of inflammation, apoptosis, and necrosis by changing the DNA chain and by perturbating its stability. Two consequences of this are the proliferation of cells and fibrosis. The result of excessive ROS generation also includes the activation of transcription factors, such as NF-kB or AP-1 proteins and pro-inflammatory mediators [93].

Antioxidant mechanisms constituted by enzymes such as SOD, CAT, GPx, and MPO are not considered in this review. We focused on exogenous antioxidants able to transform ROS into less harmful molecules. Most of these compounds have been studied for several years and include the $\mathrm{E}$ and $\mathrm{C}$ vitamins, carotenoids, and flavonoids [7].

Vitamin $\mathrm{E}$ is an effective antioxidant that has 8 isoforms. It preserves against lipid peroxidation, converting more innocuous reactive radicals to tocopherol. Some research has demonstrated the presence of doubled a-tocopherol concentrations in non-asthmatics compared to asthmatic subjects. Vitamin C exerts its action in collaboration with vitamin E. It eliminates excessive radicals and restores vitamin $\mathrm{E}$ to its original form. Carotenoids include b-carotene, which is introduced in the diet (i.e., carrots, lettuce, fruit). Once in the body, it is transformed into retinol (fundamental for eye physiology). Retinol protects against singlet oxygen. Flavonoids are typical components of plants (such as green tea, leaves, and grapes).

\subsection{Oxidative Stress, Damage, and Immune Recruitment}

The role of oxidative stress in immune system diseases was individuated as an imbalance between over-production of reactive oxygen species (ROS) or nitrogen (RNS) generated by pro-inflammatory immune cells (such as macrophages, eosinophils and monocytes) and a reduced production of antioxidants with an alteration of defense systems like CAT, SOD, GSH [94]. The emblem of this imbalance is shown by Myeloperoxidase 
(MPO) behavior. MPO is a glycosylated heme-enzyme which is stored in neutrophils and macrophages azurophilic granules; these granules could exert a huge bactericidal action due to their content. In fact they contain hypochlorous acid generated from hydrogen peroxide and chloride ions [1]. Serum levels of MPO, when increased, are used as a diagnostic marker for some diseases because it could favor the inflammation typical of as asthma, atopic dermatitis, rheumatoid arthritis, and sometimes cancers [1,94].

\subsection{Exogenous Antioxidants and Autoimmunity}

Several molecules and products were tested in order to demonstrate or confirm their antioxidant nature in autoimmune diseases. Although the results are promising, several of these exogenous antioxidants are already widespread in clinical practice $[95,96]$. Some researchers conducted their experiments by using probiotics, based on Lactobacilli and Bifidobacteria. The modification of gut microbiota was demonstrated to be promising for several diseases interfering with the immune response. Recent data also reported how microbiota could influence epigenetics and consequently inflammatory status. Probiotic administration together with a permanent gut microflora change could constitute a future therapeutic strategy both for cancer and immune-related diseases [97,98]. However, the exact mechanism involved in their antioxidant ability still remains to be clarified. It is likely due both to a direct anti-ROS function and to an indirect anti-inflammatory aptitude for preventing cellular damage and ROS release. Flavonoids also were demonstrated being promising in blocking immune system self-damage in autoimmune diseases. They act both by reducing inflammation and by regulating immune response playing at different levels. Their ability to block NF-kB was reported, therefore inhibiting the release and production of detrimental pro-inflammatory mediators. The most obvious consequence is the avoidance of further damages induced by oxidative stressors like NO and ROS [24].

More specifically, the autoimmune diseases analyzed shared some pathogenetic mechanisms and differed in others. The dietary supplementations reduced pro-inflammatory cytokines in RA and SLE $[99,100]$.

\subsection{ROS, the Immune System, and Inflammation}

Ever-increasing evidence of intimate connections between oxidative stress and chronic diseases has been reported. It was also demonstrated that oxidative stress plays an important role in cellular aging and as promoter of cancer [101]. Oxidative stress also favors tissue relapse of inflammation mediators through upregulation of their genes Immune system cells in turn, once activated, release pro-inflammatory cytokines, creating a vicious cycle [102]. Due to its inflammatory capability, oxidative stress could be of main importance in the pathogenesis of immune-related diseases. Often in autoimmune diseases there is a continuous recruitment and activation of inflammatory cells. ROS are over-generated often as a consequence of exposure to the external and internal causal agents that favor the onset of these pathologies. Free radicals, like superoxide anions and hydrogen peroxide, interfere with leukocytes (and the others cells) influencing immune function. Moreover, there is an expansion of ROS presence that occurs after the intervention and the activation of chronic inflammation, leading to a vicious cycle. This perpetuation of the stimuli and of the immune system activation in a sort of loop does seems to happen in acute pathologies [103]. There is a correlation between mitochondrial dysfunction and increased oxidative stress and the onset of autoimmune diseases. Mitochondria have a main role in many phases of the immune response; some of these fundamental processes are dendritic cell differentiation, antigen presentation, T-cell stimulation, and B-cell hyper-proliferation and activation [104]. This cascade leads to the release of pro-inflammatory cytokines (Figure 1). Antioxidants could have beneficial effects on autoimmune-related inflammation in humans; in this scenario, various nutritional compounds are capable of influencing the metabolic balance by equilibrating mitochondrial activity and ROS generation. The bidirectional cause-effect theory of the connection between mitochondrial metabolic stress and 
pathogenesis of autoimmune inflammation could in part explain the results that emerged from the literature.

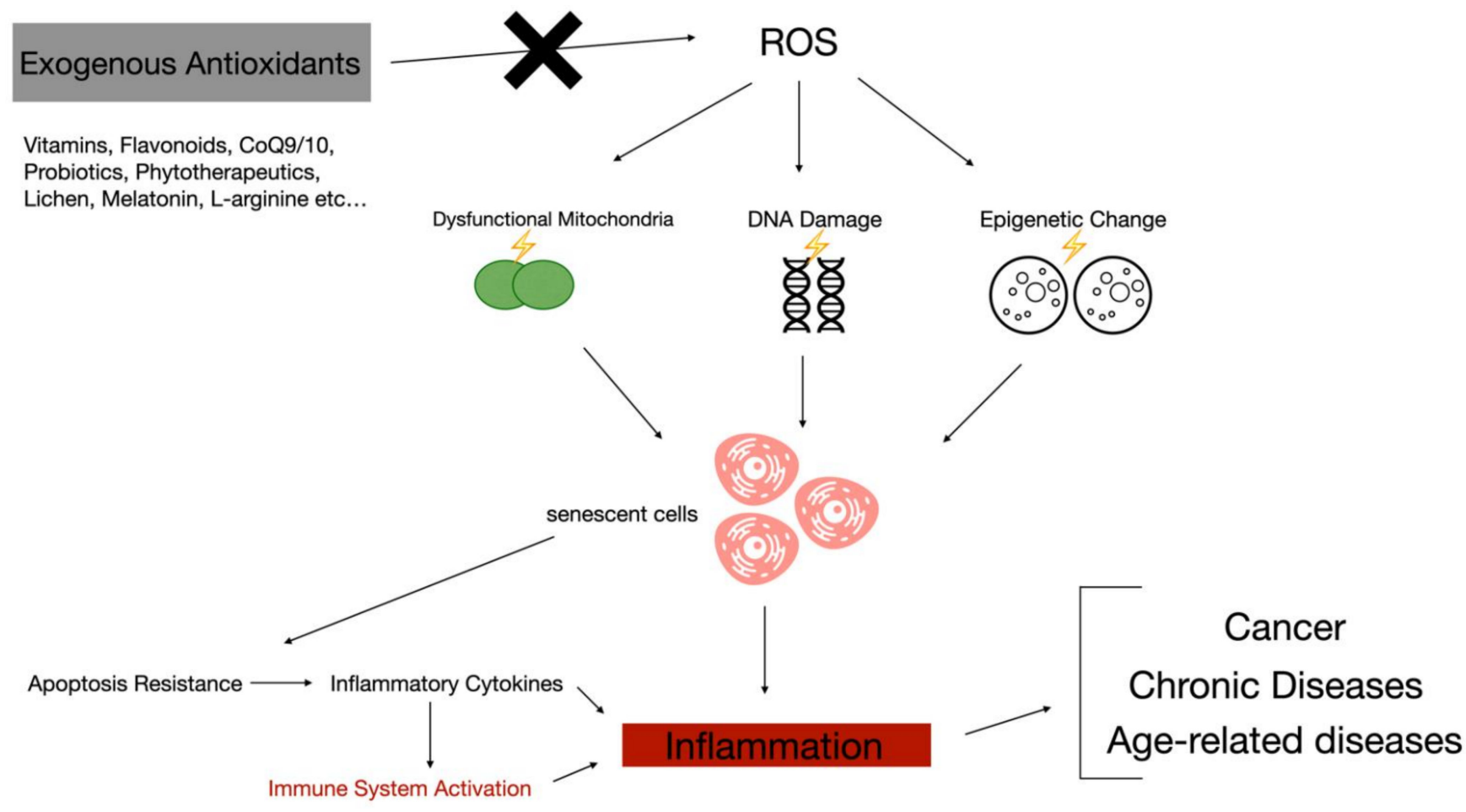

Figure 1. Some of the most studied exogenous antioxidants blocking reactive oxygen species (ROS) cascade in triggering and sustaining chronic inflammation and immune-related diseases.

\subsection{The Allergic Lesson: Antioxidant Administration as Potential Therapeutic Approach}

As mentioned above, antioxidants are enzymatic and non-enzymatic mechanisms able to counteract the damaging effect of oxidative stress. Internal constitutive antioxidants are constituted by enzymes which counterbalance ROS effects. The aim of these mechanisms is the change of radicals into less harmful molecules [105]. There are also non enzymatic and exogenous antioxidants which counterbalance oxidative stress. These compounds intake happen thanks to diet. Some examples were reported in this extensive review [106].

Several papers demonstrated antioxidant properties in vitro; however, their capabilities in vivo remain still uncertain. FeNO and other oxidative stress biomarkers in fact, reported a weak association between asthma and vitamin A and E intake benefits [107]. The role acted by dietary supplementation in the severity of asthma is still in progress. In neonatal studies, levels of selenium in maternal and cord blood predicted a minor incidence of wheeze [108]. The vantage of selenium presence in adults is still controversial. Animals had a worse outcome both with low and high selenium levels suggesting a complex role of selenium on asthma. Zinc and copper gave almost the same uncertain results [109].

It was shown Paeonia and Schisandra therapeutic effect and antioxidant activity in asthmatic disease. This extract seemed to influence the level of eosinophils, cytokines, NF-kB with an antioxidant trend. Saponins, lignans, flavonoids, and phenols are the most imputed antioxidant substances contained in the plant [110].

Nowadays, many dietary supplements are available for modifying oxidative stress, such as vitamins and minerals. Theoretically promising, dietary antioxidant drugs showed no significant benefits also in other allergic diseases. However, most studies have a high risk of bias due to the diversity of samples and diseases. However, most antioxidant supplements have no side effects. These dietary supplements are an economic burden for the patients in a long-term intake. More large scale and better-designed researches are necessary in order to fully consider the efficacy in allergic diseases [111-113]. 


\section{Conclusions}

Oxidative stress is a detrimental process that is physiologically present in human beings. This process is counterbalanced by several endogenous systems. Sometimes these protective systems are not enough and exogenous antioxidants are needed to support the innate ones. ROS cooperate in cellular damage typical of immune-related diseases and sustain additional pathological events once released after pro-inflammatory tissue disruption. This self-sustaining loop constitute one of the main checkpoints of autoimmune diseases and chronic inflammation. The administration of exogenous substances through food derivates or dietary supplements following scientific standardization was demonstrated to be effective. Further bias-free and extended studies should be conducted that include ever-increasing oxidative stress biomarkers. Antioxidant supplementation may delay the onset of some immune-related diseases and ameliorate the course of autoimmune diseases.

Supplementary Materials: The following are available online at https:/ / www.mdpi.com/2076-392 1/10/2/261/s1, Figure S1: Chemical structure of the principal exogenous antioxidants.

Author Contributions: Conceptualization, S.G., G.C. and M.N.; methodology, M.C. and C.M.; software, F.C.; validation, E.D.S., F.C. and E.E.S.; formal analysis, C.M.; investigation, M.C.; resources, G.P.; data curation, E.E.S. and E.D.S.; writing—original draft preparation, M.C. and C.M.; writingreview and editing, G.C., C.M., M.C. and S.G.; visualization, E.D.S.; supervision, M.N.; project administration, S.G.; funding acquisition, G.P. All authors have read and agreed to the published version of the manuscript.

Funding: This research did not receive any specific grant from funding agencies in the public, commercial, or not-for-profit sectors.

Conflicts of Interest: None of the authors have any conflict of interests to declare.

$\begin{array}{ll}\text { Abbreviations } \\ \text { ALA } & \text { alpha-lipoic acid } \\ \text { ALT } & \text { alanine transaminase } \\ \text { AST } & \text { aspartate transaminase } \\ \text { AP-1 } & \text { activator protein } 1 \\ \text { CAMP } & \text { cathelicidin antimicrobial peptide } \\ \text { CAT } & \text { catalase } \\ \text { CCL } & \text { chemokine motif ligand } \\ \text { CML } & \text { carboxymethylisine } \\ \text { COPD } & \text { chronic obstructive pulmonary disease } \\ \text { CoQ } & \text { Coenzyme Q } \\ \text { COXs } & \text { cyclooxygenases } \\ \text { DAMPS } & \text { damage-associated molecular patterns } \\ \text { DM } & \text { diabetes mellitus } \\ \text { DNA } & \text { deoxyribonucleic acid } \\ \text { EDSS } & \text { expanded disability status scale } \\ \text { ENA } & \text { European Nutraceutical Association } \\ \text { FeNO } & \text { fractional exhaled nitric oxide } \\ \text { FRAP } & \text { Ferric reducing antioxidant power } \\ \text { FSP } & \text { fermented soy permeate } \\ \text { GPx } & \text { glutathione peroxidase } \\ \text { GSH } & \text { glutathione } \\ \text { H } \mathrm{O}_{2} & \text { hydrogen peroxide } \\ \text { hBD } & \text { human beta defensin } \\ \text { HDL } & \text { high-density liprotein } \\ \text { Hs-CRP } & \text { high sensitivity-C-reactive protein } \\ \text { IGF } & \text { insulin-like growth factor } \\ \text { IL } & \text { interleukin }\end{array}$




\begin{tabular}{|c|c|}
\hline iNOS & inducible nitric oxide synthase \\
\hline IFN & interferon \\
\hline IP-10/CXCL10 & induced protein-10/ C-X-C motif chemokine ligand 10 \\
\hline IU & international unit \\
\hline LDL & low density lipoprotein \\
\hline MA & microalbuminuria \\
\hline MCP-1 & monocyte chemoattractant protein-1 \\
\hline MDA & malondialdehyde \\
\hline MIG & monokine induced by gamma interferon \\
\hline MIP & macrophage inflammatory protein \\
\hline MMP-3 & matrix metalloproteinase-3. \\
\hline $\mathrm{Mn}$ & manganese \\
\hline MOE & methanolic oregano extract \\
\hline MPO & myeloperoxidase \\
\hline MS & multiple sclerosis \\
\hline NAFLD & nonalcoholic fatty liver disease \\
\hline NK & natural killer \\
\hline NLRP3 & NLR family pyrin domain containing 3 \\
\hline $\mathrm{NO}$ & nitric oxide \\
\hline $\mathrm{NO}_{2}^{-}$ & nitrogen dioxide \\
\hline NF-kB & nuclear factor kappa B \\
\hline RA & rheumatoid arthritis \\
\hline RANTES & Regulated upon Activation, Normal T Cell Expressed and Presumably Secreted \\
\hline ROS & reactive oxygen species \\
\hline SLE & systemic lupus erythematosus \\
\hline SOD & superoxide dismutase \\
\hline TAC & total antioxidant capacity \\
\hline TAS & total antioxidative status \\
\hline Th & T helper \\
\hline TNF- $\alpha$ & tumor necrosis factor-alpha \\
\hline TXNIP & thioredoxin-interacting protein \\
\hline VEC & vitamin $\mathrm{E}$ content \\
\hline VEGF & vascular endothelial growth factor \\
\hline WBCT & whole-body cryotherapy treatment \\
\hline
\end{tabular}

\section{References}

1. Casciaro, M.; di Salvo, E.; Pace, E.; Ventura-Spagnolo, E.; Navarra, M.; Gangemi, S. Chlorinative Stress in Age-Related Diseases: A Literature Review. Immun. Ageing 2017, 14, 1-7. [CrossRef] [PubMed]

2. Wang, Y.; Li, S.; Li, C. Perspectives of New Advances in the Pathogenesis of Vitiligo: From Oxidative Stress to Autoimmunity. Med. Sci. Monit. Int. Med. J. Exp. Clin. Res. 2019, 25, 1017. [CrossRef] [PubMed]

3. Ruggeri, R.M.; Vicchio, T.M.; Cristani, M.; Certo, R.; Caccamo, D.; Alibrandi, A.; Giovinazzo, S.; Saija, A.; Campennì, A.; Trimarchi, F.; et al. Oxidative Stress and Advanced Glycation End Products in Hashimoto's Thyroiditis. Thyroid 2016, 26, 504-511. [CrossRef]

4. Aryaeian, N.; Shahram, F.; Mahmoudi, M.; Tavakoli, H.; Yousefi, B.; Arablou, T.; Karegar, S.J. The Effect of Ginger Supplementation on Some Immunity and Inflammation Intermediate Genes Expression in Patients with Active Rheumatoid Arthritis. Gene 2019, 698, 179-185. [CrossRef] [PubMed]

5. Vaccaro, M.; Bagnato, G.; Cristani, M.; Borgia, F.; Spatari, G.; Tigano, V.; Saja, A.; Guarneri, F.; Cannavò, S.P.; Gangemi, S. Oxidation Products Are Increased in Patients Affected by Non-Segmental Generalized Vitiligo. Arch. Dermatol. Res. 2017, 309, 485-490. [CrossRef] [PubMed]

6. Cannavò, S.P.; Riso, G.; Casciaro, M.; di Salvo, E.; Gangemi, S. Oxidative Stress Involvement in Psoriasis: A Systematic Review. Free Radic. Res. 2019, 53, 829-840. [CrossRef]

7. Carr, A.C.; Maggini, S. Vitamin C and Immune Function. Nutrients 2017, 9. [CrossRef] [PubMed]

8. Martel, J.; Ojcius, D.M.; Ko, Y.-F.; Ke, P.-Y.; Wu, C.-Y.; Peng, H.-H.; Young, J.D. Hormetic Effects of Phytochemicals on Health and Longevity. Trends Endocrinol. Metab. 2019, 30, 335-346. [CrossRef]

9. Martucci, M.; Ostan, R.; Biondi, F.; Bellavista, E.; Fabbri, C.; Bertarelli, C.; Salvioli, S.; Capri, M.; Franceschi, C.; Santoro, A. Mediterranean Diet and Inflammaging within the Hormesis Paradigm. Nutr. Rev. 2017, 75, 442-455. [CrossRef]

10. Kumar, M.; Kaur, V.; Kumar, S.; Kaur, S. Phytoconstituents as Apoptosis Inducing Agents: Strategy to Combat Cancer. Cytotechnology 2016, 68, 531-563. [CrossRef] [PubMed]

11. Kalra, E.K. Nutraceutical-Definition and Introduction. Aaps Pharmsci. 2003, 5, 27-28. [CrossRef] [PubMed] 
12. Nasri, H.; Baradaran, A.; Shirzad, H.; Rafieian-Kopaei, M. New Concepts in Nutraceuticals as Alternative for Pharmaceuticals. Int. J. Prev. Med. 2014, 5, 1487-1499.

13. Télessy, I.G. Nutraceuticals. In The Role of Functional Food Security in Global Health; Elsevier: Amsterdam, The Netherlands, 2019; pp. 409-421.

14. European Nutraceutical Association I LinkedIn. Available online: https://it.linkedin.com/company/european-nutraceuticalassociation (accessed on 29 January 2021).

15. Aronson, J.K. Defining 'Nutraceuticals': Neither Nutritious nor Pharmaceutical. Br. J. Clin. Pharm. 2017, 83, 8-19. [CrossRef]

16. Caraffa, A.L.; Varvara, G.; Spinas, E.; Kritas, S.K.; Lessiani, G.; Ronconi, G.; Saggini, A.; Antinolfi, P.; Frydas, I.; de Tommaso Morrison, M.C.; et al. Is Vitamin E an Anti-Allergic Compound? J. Biol. Regul. Homeost. Agents 2016, 30, 11-15. [PubMed]

17. Choi, S.M.; Lim, D.S.; Kim, M.K.; Yoon, S.; Kacew, S.; Kim, H.S.; Lee, B.-M. Inhibition of Di(2-Ethylhexyl) Phthalate (DEHP)Induced Endocrine Disruption by Co-Treatment of Vitamins C and E and Their Mechanism of Action. J. Toxicol. Env. Health A 2018, 81, 748-760. [CrossRef] [PubMed]

18. Edge, R.; Truscott, T.G. Singlet Oxygen and Free Radical Reactions of Retinoids and Carotenoids-A Review. Antioxidants 2018, 7. [CrossRef] [PubMed]

19. Murdaca, G.; Tonacci, A.; Negrini, S.; Greco, M.; Borro, M.; Puppo, F.; Gangemi, S. Emerging Role of Vitamin D in Autoimmune Diseases: An Update on Evidence and Therapeutic Implications. Autoimmun. Rev. 2019, 18, 102350. [CrossRef] [PubMed]

20. Sintov, A.C.; Yarmolinsky, L.; Dahan, A.; Ben-Shabat, S. Pharmacological Effects of Vitamin D and Its Analogs: Recent Developments. Drug Discov. Today 2014, 19, 1769-1774. [CrossRef] [PubMed]

21. Tang, L.; Fang, W.; Lin, J.; Li, J.; Wu, W.; Xu, J. Vitamin D Protects Human Melanocytes against Oxidative Damage by Activation of Wnt/ $\beta$-Catenin Signaling. Lab. Investig. 2018, 98, 1527-1537. [CrossRef]

22. Illescas-Montes, R.; Melguizo-Rodríguez, L.; Ruiz, C.; Costela-Ruiz, V.J. Vitamin D and Autoimmune Diseases. Life Sci. 2019, 233, 116744. [CrossRef]

23. Panche, A.N.; Diwan, A.D.; Chandra, S.R. Flavonoids: An Overview. J. Nutr. Sci. 2016, 5. [CrossRef] [PubMed]

24. Rengasamy, K.R.R.; Khan, H.; Gowrishankar, S.; Lagoa, R.J.L.; Mahomoodally, F.M.; Khan, Z.; Suroowan, S.; Tewari, D.; Zengin, G.; Hassan, S.T.S.; et al. The Role of Flavonoids in Autoimmune Diseases: Therapeutic Updates. Pharmacol. Ther. 2019, 194, 107-131. [CrossRef] [PubMed]

25. Tuñón, M.J.; García-Mediavilla, M.V.; Sánchez-Campos, S.; González-Gallego, J. Potential of Flavonoids as Anti-Inflammatory Agents: Modulation of pro-Inflammatory Gene Expression and Signal Transduction Pathways. Curr. Drug Metab. 2009, 10, 256-271. [CrossRef]

26. Ribeiro, D.; Freitas, M.; Lima, J.L.F.C.; Fernandes, E. Proinflammatory Pathways: The Modulation by Flavonoids. Med. Res. Rev. 2015, 35, 877-936. [CrossRef]

27. Wold, L.E.; Muralikrishnan, D.; Albano, C.B.; Norby, F.L.; Ebadi, M.; Ren, J. Insulin-like Growth Factor I (IGF-1) Supplementation Prevents Diabetesinduced Alterations in Coenzymes Q 9 and Q 10. Acta Diabetol. 2003, 40, 85-90. [CrossRef] [PubMed]

28. Lee, B.J.; Tseng, Y.F.; Yen, C.H.; Lin, P.T. Effects of Coenzyme Q10 Supplementation (300 Mg/Day) on Antioxidation and Anti-Inflammation in Coronary Artery Disease Patients during Statins Therapy: A Randomized, Placebo-Controlled Trial. Nutr. J. 2013, 12, 142. [CrossRef]

29. Albano, C.B.; Muralikrishnan, D.; Ebadi, M. Distribution of Coenzyme Q Homologues in Brain. Neurochem. Res. 2002, 27, 359-368. [CrossRef] [PubMed]

30. Battino, M.; Gorini, A.; Villa, R.F.; Genova, M.L.; Bovina, C.; Sassi, S.; Littarru, G.P.; Lenaz, G. Coenzyme Q Content in Synaptic and Non-Synaptic Mitochondria from Different Brain Regions in the Ageing Rat. Mech. Ageing Dev. 1995, 78, 173-187. [CrossRef]

31. Rauscher, F.M.; Sanders, R.A.; Watkins, J.B. Effects of Coenzyme Q10 Treatment on Antioxidant Pathways in Normal and Streptozotocin-Induced Diabetic Rats. J. Biochem. Mol. Toxicol. 2001, 15, 41-46. [CrossRef]

32. Liu, Y.; Alookaran, J.J.; Rhoads, J.M. Probiotics in Autoimmune and Inflammatory Disorders. Nutrients $2018,10,1537$. [CrossRef] [PubMed]

33. Ishizaki, A.; Bi, X.; Nguyen, L.V.; Matsuda, K.; Pham, H.V.; Phan, C.T.T.; Khu, D.T.K.; Ichimura, H. Effects of Short-Term Probiotic Ingestion on Immune Profiles and Microbial Translocation among HIV-1-Infected Vietnamese Children. Int. J. Mol. Sci. 2017, 18. [CrossRef]

34. Mohammed, A.T.; Khattab, M.; Ahmed, A.M.; Turk, T.; Sakr, N.; Khalil, A.M.; Abdelhalim, M.; Sawaf, B.; Hirayama, K.; Huy, N.T. The Therapeutic Effect of Probiotics on Rheumatoid Arthritis: A Systematic Review and Meta-Analysis of Randomized Control Trials. Clin. Rheumatol. 2017, 36, 2697-2707. [CrossRef]

35. Vitaliti, G.; Pavone, P.; Guglielmo, F.; Spataro, G.; Falsaperla, R. The Immunomodulatory Effect of Probiotics beyond Atopy: An Update. J. Asthma 2014, 51, 320-332. [CrossRef]

36. Choi, H.; Cho, S.Y.; Pak, H.J.; Kim, Y.; Choi, J.Y.; Lee, Y.J.; Gong, B.H.; Kang, Y.S.; Han, T.; Choi, G.; et al. NPCARE: Database of Natural Products and Fractional Extracts for Cancer Regulation. J. Cheminform. 2017, 9, 2. [CrossRef]

37. Petrovska, B.B.; Cekovska, S. Extracts from the History and Medical Properties of Garlic. Pharmacogn. Rev. 2010, 4, 106. [CrossRef] [PubMed]

38. Cellini, L.; Campli, E.D.; Masulli, M.; Bartolomeo, S.D.; Allocati, N. Inhibition of Helicobacter Pylori by Garlic Extract (Allium Sativum). FEMS Immunol. Med. Microbiol. 1996, 13, 273-277. [CrossRef] [PubMed] 
39. Goncagul, G.; Ayaz, E. Antimicrobial Effect of Garlic (Allium Sativum). Recent Pat. Antiinfect. Drug Discov. 2010, 5, 91-93. [CrossRef] [PubMed]

40. Sajem, A.L.; Gosai, K. Traditional Use of Medicinal Plants by the Jaintia Tribes in North Cachar Hills District of Assam, Northeast India. J. Ethnobiol. Ethnomed. 2006, 2, 33. [CrossRef]

41. Majumder, M.; Debnath, S.; Gajbhiye, R.L.; Saikia, R.; Gogoi, B.; Samanta, S.K.; Das, D.K.; Biswas, K.; Jaisankar, P.; Mukhopadhyay, R. Ricinus Communis L. Fruit Extract Inhibits Migration/Invasion, Induces Apoptosis in Breast Cancer Cells and Arrests Tumor Progression in Vivo. Sci. Rep. 2019, 9. [CrossRef] [PubMed]

42. Yin, H.; Fretté, X.C.; Christensen, L.P.; Grevsen, K. Chitosan Oligosaccharides Promote the Content of Polyphenols in Greek Oregano (Origanum Vulgare Ssp. Hirtum). J. Agric. Food Chem. 2012, 60, 136-143. [CrossRef]

43. Esen, G.; Azaz, A.D.; Kurkcuoglu, M.; Baser, K.H.C.; Tinmaz, A. Essential Oil and Antimicrobial Activity of Wild and Cultivated Origanum Vulgare L. Subsp. Hirtum (Link) Letswaart from the Marmara Region, Turkey. Flavour Fragr. J. 2007. Available online: https: / / onlinelibrary.wiley.com/doi/10.1002/ffj.1808 (accessed on 24 November 2020). [CrossRef]

44. Bright, J.J. Curcumin and Autoimmune Disease. Adv. Exp. Med. Biol. 2007, 595, 425-451. [CrossRef]

45. Fernández-Moriano, C.; Gómez-Serranillos, M.P.; Crespo, A. Antioxidant Potential of Lichen Species and Their Secondary Metabolites. A Systematic Review. Pharm. Biol. 2016, 54, 1-17. [CrossRef] [PubMed]

46. Rodriguez, C.; Mayo, J.C.; Sainz, R.M.; Antolín, I.; Herrera, F.; Martín, V.; Reiter, R.J. Regulation of Antioxidant Enzymes: A Significant Role for Melatonin. J. Pineal Res. 2004, 36, 1-9. [CrossRef]

47. Reiter, R.J.; Mayo, J.C.; Tan, D.-X.; Sainz, R.M.; Alatorre-Jimenez, M.; Qin, L. Melatonin as an Antioxidant: Under Promises but over Delivers. J. Pineal Res. 2016, 61, 253-278. [CrossRef]

48. Liang, M.; Wang, Z.; Li, H.; Cai, L.; Pan, J.; He, H.; Wu, Q.; Tang, Y.; Ma, J.; Yang, L. L-Arginine Induces Antioxidant Response to Prevent Oxidative Stress via Stimulation of Glutathione Synthesis and Activation of Nrf2 Pathway. Food Chem. Toxicol. 2018, 115, 315-328. [CrossRef]

49. Li, X.; Bi, X.; Wang, S.; Zhang, Z.; Li, F.; Zhao, A.Z. Therapeutic Potential of $\omega$-3 Polyunsaturated Fatty Acids in Human Autoimmune Diseases. Front. Immunol. 2019, 10, 2241. [CrossRef] [PubMed]

50. Avery, J.; Hoffmann, P. Selenium, Selenoproteins, and Immunity. Nutrients 2018, 10, 1203. [CrossRef] [PubMed]

51. Wichman, J.; Winther, K.H.; Bonnema, S.J.; Hegedüs, L. Selenium Supplementation Significantly Reduces Thyroid Autoantibody Levels in Patients with Chronic Autoimmune Thyroiditis: A Systematic Review and Meta-Analysis. Thyroid 2016, 26, 1681-1692. [CrossRef]

52. Sanna, A.; Firinu, D.; Zavattari, P.; Valera, P. Zinc Status and Autoimmunity: A Systematic Review and Meta-Analysis. Nutrients 2018, 10. [CrossRef]

53. Mirtaheri, E.; Pourghassem Gargari, B.; Kolahi, S.; Dehghan, P.; Asghari-Jafarabadi, M.; Hajalilou, M.; Shakiba Novin, Z.; Mesgari Abbasi, M. Effects of Alpha-Lipoic Acid Supplementation on Inflammatory Biomarkers and Matrix Metalloproteinase-3 in Rheumatoid Arthritis Patients. J. Am. Coll. Nutr. 2015, 34, 310-317. [CrossRef] [PubMed]

54. Scaramuzza, A.; Giani, E.; Redaelli, F.; Ungheri, S.; Macedoni, M.; Giudici, V.; Bosetti, A.; Ferrari, M.; Zuccotti, G.V. Alpha-Lipoic Acid and Antioxidant Diet Help to Improve Endothelial Dysfunction in Adolescents with Type 1 Diabetes: A Pilot Trial. J. Diabetes Res. 2015, 2015, 474561. [CrossRef]

55. Fayh, A.P.T.; Krause, M.; Rodrigues-Krause, J.; Ribeiro, J.L.; Ribeiro, J.P.; Friedman, R.; Moreira, J.C.F.; Reischak-Oliveira, A. Effects of L-Arginine Supplementation on Blood Flow, Oxidative Stress Status and Exercise Responses in Young Adults with Uncomplicated Type I Diabetes. Eur. J. Nutr. 2013, 52, 975-983. [CrossRef]

56. Abdollahzad, H.; Aghdashi, M.A.; Jafarabadi, M.A.; Alipour, B. Effects of Coenzyme Q10 Supplementation on Inflammatory Cytokines (TNF- $\alpha$, IL-6) and Oxidative Stress in Rheumatoid Arthritis Patients: A Randomized Controlled Trial. Arch. Med. Res. 2015, 46, 527-533. [CrossRef]

57. Sanoobar, M.; Eghtesadi, S.; Azimi, A.; Khalili, M.; Khodadadi, B.; Jazayeri, S.; Gohari, M.R.; Aryaeian, N. Coenzyme Q10 Supplementation Ameliorates Inflammatory Markers in Patients with Multiple Sclerosis: A Double Blind, Placebo, Controlled Randomized Clinical Trial. Nutr. Neurosci. 2015, 18, 169-176. [CrossRef]

58. Sanoobar, M.; Dehghan, P.; Khalili, M.; Azimi, A.; Seifar, F. Coenzyme Q10 as a Treatment for Fatigue and Depression in Multiple Sclerosis Patients: A Double Blind Randomized Clinical Trial. Nutr. Neurosci. 2016, 19, 138-143. [CrossRef] [PubMed]

59. Brauner, H.; Luthje, P.; Grunler, J.; Ekberg, N.R.; Dallner, G.; Brismar, K.; Brauner, A. Markers of Innate Immune Activity in Patients with Type 1 and Type 2 Diabetes Mellitus and the Effect of the Anti-Oxidant Coenzyme Q10 on Inflammatory Activity. Clin. Exp. Immunol. 2014, 177, 478-482. [CrossRef] [PubMed]

60. Vasiljevic, D.; Veselinovic, M.; Jovanovic, M.; Jeremic, N.; Arsic, A.; Vucic, V.; Lucic-Tomic, A.; Zivanovic, S.; Djuric, D.; Jakovljevic, V. Evaluation of the Effects of Different Supplementation on Oxidative Status in Patients with Rheumatoid Arthritis. Clin. Rheumatol. 2016, 35, 1909-1915. [CrossRef] [PubMed]

61. Arriens, C.; Hynan, L.S.; Lerman, R.H.; Karp, D.R.; Mohan, C. Placebo-Controlled Randomized Clinical Trial of Fish Oil's Impact on Fatigue, Quality of Life, and Disease Activity in Systemic Lupus Erythematosus. Nutr. J. 2015, 14, 82. [CrossRef]

62. Miller, E.; Mrowicka, M.; Malinowska, K.; Kedziora, J.; Majsterek, I. The Effects of Whole-Body Cryotherapy and Melatonin Supplementation on Total Antioxidative Status and Some Antioxidative Enzymes in Multiple Sclerosis Patients. Pol. Merkur. Lek. Organ Pol. Tow. Lek. 2011, 31, 150-153. 
63. Adamczyk-Sowa, M.; Sowa, P.; Mucha, S.; Zostawa, J.; Mazur, B.; Owczarek, M.; Pierzchała, K. Changes in Serum Ceruloplasmin Levels Based on Immunomodulatory Treatments and Melatonin Supplementation in Multiple Sclerosis Patients. Med. Sci. Monit. Int. Med. J. Exp. Clin. Res. 2016, 22, 2484. [CrossRef] [PubMed]

64. Vaghef-Mehrabany, E.; Homayouni-Rad, A.; Alipour, B.; Sharif, S.-K.; Vaghef-Mehrabany, L.; Alipour-Ajiry, S. Effects of Probiotic Supplementation on Oxidative Stress Indices in Women with Rheumatoid Arthritis: A Randomized Double-Blind Clinical Trial. J. Am. Coll. Nutr. 2016, 35, 291-299. [CrossRef]

65. Kouchaki, E.; Tamtaji, O.R.; Salami, M.; Bahmani, F.; Kakhaki, R.D.; Akbari, E.; Tajabadi-Ebrahimi, M.; Jafari, P.; Asemi, Z. Clinical and Metabolic Response to Probiotic Supplementation in Patients with Multiple Sclerosis: A Randomized, Double-Blind, Placebo-Controlled Trial. Clin. Nutr. 2017, 36, 1245-1249. [CrossRef] [PubMed]

66. Helli, B.; Mowla, K.; Mohammadshahi, M.; Jalali, M.T. Effect of Sesamin Supplementation on Cardiovascular Risk Factors in Women with Rheumatoid Arthritis. J. Am. Coll. Nutr. 2016, 35, 300-307. [CrossRef]

67. Nemes-Nagy, E.; Szőcs-Molnár, T.; Dunca, I.; Balogh-Sămărghiţan, V.; Hobai, Ş.; Morar, R.; Pusta, D.L.; Crăciun, E.C. Effect of a Dietary Supplement Containing Blueberry and Sea Buckthorn Concentrate on Antioxidant Capacity in Type 1 Diabetic Children. Acta Physiol. Hung. 2008, 95, 383-393. [CrossRef]

68. Tam, L.S.; Li, E.K.; Leung, V.Y.; Griffith, J.F.; Benzie, I.F.; Lim, P.L.; Whitney, B.; Lee, V.W.; Lee, K.K.; Thomas, G.N. Effects of Vitamins C and E on Oxidative Stress Markers and Endothelial Function in Patients with Systemic Lupus Erythematosus: A Double Blind, Placebo Controlled Pilot Study. J. Rheumatol. 2005, 32, 275-282.

69. Kouchaki, E.; Afarini, M.; Abolhassani, J.; Mirhosseini, N.; Bahmani, F.; Masoud, S.A.; Asemi, Z. High-Dose $\omega-3$ Fatty Acid plus Vitamin D3 Supplementation Affects Clinical Symptoms and Metabolic Status of Patients with Multiple Sclerosis: A Randomized Controlled Clinical Trial. J. Nutr. 2018, 148, 1380-1386. [CrossRef]

70. Jain, S.K.; Krueger, K.S.; McVie, R.; Jaramillo, J.J.; Palmer, M.; Smith, T. Relationship of Blood Thromboxane-B2 (TxB2) with Lipid Peroxides and Effect of Vitamin E and Placebo Supplementation on TxB2 and Lipid Peroxide Levels in Type 1 Diabetic Patients. Diabetes Care 1998, 21, 1511-1516. [CrossRef] [PubMed]

71. Şardaş, S.; Yilmaz, M.; Öztok, U.; Çakir, N.; Karakaya, A.E. Assessment of DNA Strand Breakage by Comet Assay in Diabetic Patients and the Role of Antioxidant Supplementation. Mutat. Res. Genet. Toxicol. Environ. Mutagenesis 2001, 490, 123-129. [CrossRef]

72. Giannini, C.; Lombardo, F.; Curro, F.; Pomilio, M.; Bucciarelli, T.; Chiarelli, F.; Mohn, A. Effects of High-dose Vitamin E Supplementation on Oxidative Stress and Microalbuminuria in Young Adult Patients with Childhood Onset Type 1 Diabetes Mellitus. Diabetes/Metab. Res. Rev. 2007, 23, 539-546. [CrossRef] [PubMed]

73. Gupta, S.; Sharma, T.K.; Kaushik, G.G.; Shekhawat, V.P. Vitamin E Supplementation May Ameliorate Oxidative Stress in Type 1 Diabetes Mellitus Patients. Clin. Lab. 2011, 57, 379.

74. Cazeau, R.M.; Huang, H.; Bauer, J.A.; Hoffman, R.P. Effect of Vitamins C and E on Endothelial Function in Type 1 Diabetes Mellitus. J. Diabetes Res. 2016, 2016, 3271293. [CrossRef]

75. Hossein Nia, B.; Khorram, S.; Rezazadeh, H.; Safaiyan, A.; Tarighat-Esfanjani, A. The Effects of Natural Clinoptilolite and Nano-Sized Clinoptilolite Supplementation on Glucose Levels and Oxidative Stress in Rats With Type 1 Diabetes. Can. J. Diabetes 2018, 42, 31-35. [CrossRef]

76. Shivanna, N.; Naika, M.; Khanum, F.; Kaul, V.K. Antioxidant, Anti-Diabetic and Renal Protective Properties of Stevia Rebaudiana. J. Diabetes Complicat. 2013, 27, 103-113. [CrossRef] [PubMed]

77. Wang, W.; Wang, C.; Ding, X.Q.; Pan, Y.; Gu, T.T.; Wang, M.X.; Liu, Y.L.; Wang, F.M.; Wang, S.J.; Kong, L.D. Quercetin and Allopurinol Reduce Liver Thioredoxin-Interacting Protein to Alleviate Inflammation and Lipid Accumulation in Diabetic Rats. Br. J. Pharmacol. 2013, 169, 1352-1371. [CrossRef] [PubMed]

78. Malardé, L.; Groussard, C.; Lefeuvre-Orfila, L.; Vincent, S.; Efstathiou, T.; Gratas-Delamarche, A. Fermented Soy Permeate Reduces Cytokine Level and Oxidative Stress in Streptozotocin-Induced Diabetic Rats. J. Med. Food 2015, 18, 67-75. [CrossRef]

79. Tsai, P.-H.; Yeh, C.-L.; Liu, J.-J.; Chiu, W.-C.; Yeh, S.-L. Effects of Dietary Glutamine on Inflammatory Mediator Gene Expressions in Rats with Streptozotocin-Induced Diabetes. Nutrition 2012, 28, 288-293. [CrossRef] [PubMed]

80. Çolak, S.; Geyikoğlu, F.; Bakır, T.; Türkez, H.; Aslan, A. Evaluating the Toxic and Beneficial Effects of Lichen Extracts in Normal and Diabetic Rats. Toxicol. Ind. Health 2016, 32, 1495-1504. [CrossRef]

81. Park, J.-H.; Jung, J.-H.; Yang, J.-Y.; Kim, H.-S. Olive Leaf Down-Regulates the Oxidative Stress and Immune Dysregulation in Streptozotocin-Induced Diabetic Mice. Nutr. Res. 2013, 33, 942-951. [CrossRef] [PubMed]

82. Vujicic, M.; Nikolic, I.; Kontogianni, V.G.; Saksida, T.; Charisiadis, P.; Orescanin-Dusic, Z.; Blagojevic, D.; Stosic-Grujicic, S.; Tzakos, A.G.; Stojanovic, I. Methanolic Extract of Origanum Vulgare Ameliorates Type 1 Diabetes through Antioxidant, Anti-Inflammatory and Anti-Apoptotic Activity. Br. J. Nutr. 2015, 113, 770-782. [CrossRef] [PubMed]

83. Punaro, G.R.; Maciel, F.R.; Rodrigues, A.M.; Rogero, M.M.; Bogsan, C.S.B.; Oliveira, M.N.; Ihara, S.S.M.; Araujo, S.R.R.; Sanches, T.R.C.; Andrade, L.C.; et al. Kefir Administration Reduced Progression of Renal Injury in STZ-Diabetic Rats by Lowering Oxidative Stress. Nitric Oxide Biol. Chem. 2014, 37, 53-60. [CrossRef] [PubMed]

84. Özcelik, D.; Nazıroglu, M.; Tunçdemir, M.; Çelik, Ö.; Öztürk, M.; Flores-Arce, M.F. Zinc Supplementation Attenuates Metallothionein and Oxidative Stress Changes in Kidney of Streptozotocin-Induced Diabetic Rats. Biol. Trace Elem. Res. 2012, 150, 342-349. [CrossRef] 
85. Guo, Q.; Wang, Y.; Xu, D.; Nossent, J.; Pavlos, N.J.; Xu, J. Rheumatoid Arthritis: Pathological Mechanisms and Modern Pharmacologic Therapies. Bone Res. 2018, 6, 15. [CrossRef]

86. Brennan, F.M.; McInnes, I.B. Evidence That Cytokines Play a Role in Rheumatoid Arthritis. J. Clin. Investig. 2008, 118, 3537-3545. [CrossRef]

87. Scher, J.U.; Abramson, S.B. The Microbiome and Rheumatoid Arthritis. Nat. Rev. Rheumatol. 2011, 7, 569. [CrossRef] [PubMed]

88. Fava, A.; Petri, M. Systemic Lupus Erythematosus: Diagnosis and Clinical Management. J. Autoimmun. 2019, 96, 1-13. [CrossRef]

89. Parvaneh, V.J.; Jari, M.; Qhasemi, S.; Nasehi, M.M.; Rahmani, K.; Shiari, R. Guillain-Barre Syndrome as the First Manifestation of Juvenile Systemic Lupus Erythematosus: A Case Report. Open Access Rheumatol. Res. Rev. 2019, 11, 97. [CrossRef]

90. Beenakker, E.A.C.; Oparina, T.I.; Hartgring, A.; Teelken, A.; Arutjunyan, A.V.; de Keyser, J. Cooling Garment Treatment in MS: Clinical Improvement and Decrease in Leukocyte NO Production. Neurology 2001, 57, 892. [CrossRef] [PubMed]

91. Skyrme-Jones, R.A.P.; O’Brien, R.C.; Luo, M.; Meredith, I.T. Endothelial Vasodilator Function Is Related to Low-Density Lipoprotein Particle Size and Low-Density Lipoprotein Vitamin E Content in Type 1 Diabetes. J. Am. Coll. Cardiol. 2000, 35, 292-299. [CrossRef]

92. López-Miranda, J.; Pérez-Jiménez, F.; Ros, E.; de Caterina, R.; Badimón, L.; Covas, M.I.; Escrich, E.; Ordovás, J.M.; Soriguer, F.; Abiá, R.; et al. Olive Oil and Health: Summary of the II International Conference on Olive Oil and Health Consensus Report, Jaén and Córdoba (Spain) 2008. Nutr. Metab. Cardiovasc. Dis. 2010, 20, 284-294. [CrossRef]

93. Franchina, D.G.; Dostert, C.; Brenner, D. Reactive Oxygen Species: Involvement in T Cell Signaling and Metabolism. Trends Immunol. 2018, 39, 489-502. [CrossRef] [PubMed]

94. Topic, A.; Francuski, D.; Nikolic, A.; Milosevic, K.; Jovicic, S.; Markovic, B.; Djukic, M.; Radojkovic, D. The Role of Oxidative Stress in the Clinical Manifestations of Childhood Asthma. Fetal Pediatr. Pathol. 2017, 36, 294-303. [CrossRef] [PubMed]

95. Venkatesha, S.H.; Dudics, S.; Astry, B.; Moudgil, K.D. Control of Autoimmune Inflammation by Celastrol, a Natural Triterpenoid. Pathog. Dis. 2016, 74. [CrossRef] [PubMed]

96. Gianchecchi, E.; Fierabracci, A. Insights on the Effects of Resveratrol and Some of Its Derivatives in Cancer and Autoimmunity: A Molecule with a Dual Activity. Antioxidants 2020, 9. [CrossRef] [PubMed]

97. Allegra, A.; Musolino, C.; Tonacci, A.; Pioggia, G.; Gangemi, S. Interactions between the MicroRNAs and Microbiota in Cancer Development: Roles and Therapeutic Opportunities. Cancers 2020, 12. [CrossRef]

98. Casciaro, M.; di Salvo, E.; Pioggia, G.; Gangemi, S. Microbiota and MicroRNAs in Lung Diseases: Mutual Influence and Role Insights. Eur. Rev. Med. Pharm. Sci. 2020, 24, 13000-13008. [CrossRef]

99. Constantin, M.-M.; Nita, I.E.; Olteanu, R.; Constantin, T.; Bucur, S.; Matei, C.; Raducan, A. Significance and Impact of Dietary Factors on Systemic Lupus Erythematosus Pathogenesis. Exp. Med. 2019, 17, 1085-1090. [CrossRef] [PubMed]

100. Petersson, S.; Philippou, E.; Rodomar, C.; Nikiphorou, E. The Mediterranean Diet, Fish Oil Supplements and Rheumatoid Arthritis Outcomes: Evidence from Clinical Trials. Autoimmun. Rev. 2018, 17, 1105-1114. [CrossRef] [PubMed]

101. Rayess, H.; Wang, M.B.; Srivatsan, E.S. Cellular Senescence and Tumor Suppressor Gene P16. Int. J. Cancer 2012, 130, 1715-1725. [CrossRef]

102. Prasad, K.N. Oxidative Stress, Pro-Inflammatory Cytokines, and Antioxidants Regulate Expression Levels of MicroRNAs in Parkinson's Disease. Curr. Aging Sci. 2017, 10, 177-184. [CrossRef]

103. Tavassolifar, M.J.; Vodjgani, M.; Salehi, Z.; Izad, M. The Influence of Reactive Oxygen Species in the Immune System and Pathogenesis of Multiple Sclerosis. Autoimmune Dis. 2020, 2020, 5793817. [CrossRef] [PubMed]

104. Tsai, C.-Y.; Hsieh, S.-C.; Lu, C.-S.; Wu, T.-H.; Liao, H.-T.; Wu, C.-H.; Li, K.-J.; Kuo, Y.-M.; Lee, H.-T.; Shen, C.-Y.; et al. Cross-Talk between Mitochondrial Dysfunction-Provoked Oxidative Stress and Aberrant Noncoding RNA Expression in the Pathogenesis and Pathophysiology of SLE. Int. J. Mol. Sci. 2019, 20. [CrossRef]

105. Espinós, C.; Galindo, M.I.; García-Gimeno, M.A.; Ibáñez-Cabellos, J.S.; Martínez-Rubio, D.; Millán, J.M.; Rodrigo, R.; Sanz, P.; Seco-Cervera, M.; Sevilla, T.; et al. Oxidative Stress, a Crossroad between Rare Diseases and Neurodegeneration. Antioxidants 2020, 9. [CrossRef]

106. Birben, E.; Sahiner, U.M.; Sackesen, C.; Erzurum, S.; Kalayci, O. Oxidative Stress and Antioxidant Defense. World Allergy Organ. J. 2012, 5, 9-19. [CrossRef]

107. Baines, K.J.; Pavord, I.D.; Gibson, P.G. The Role of Biomarkers in the Management of Airways Disease. Int. J. Tuberc. Lung Dis. 2014, 18, 1264-1268. [CrossRef] [PubMed]

108. Baïz, N.; Chastang, J.; Ibanez, G.; Annesi-Maesano, I. Prenatal Exposure to Selenium May Protect against Wheezing in Children by the Age of 3. Immun. Inflamm. Dis. 2016, 5, 37-44. [CrossRef] [PubMed]

109. Norton, R.L.; Hoffmann, P.R. Selenium and Asthma. Mol. Asp. Med. 2012, 33, 98-106. [CrossRef]

110. Chen, X.; Huang, Y.; Feng, J.; Jiang, X.-F.; Xiao, W.-F.; Chen, X.-X. Antioxidant and Anti-Inflammatory Effects of Schisandra and Paeonia Extracts in the Treatment of Asthma. Exp. Med. 2014, 8, 1479-1483. [CrossRef]

111. Parthasarathy, L.; Khadilkar, V.; Chiplonkar, S.; Khadilkar, A. Effect of Antioxidant Supplementation on Total Antioxidant Status in Indian Children with Type 1 Diabetes. J. Diet. Suppl. 2019, 16, 390-400. [CrossRef]

112. Torres-Borrego, J.; Moreno-Solís, G.; Molina-Terán, A.B. Diet for the Prevention of Asthma and Allergies in Early Childhood: Much Ado about Something? Allergol. Immunopathol. 2012, 40, 244-252. [CrossRef]

113. Lis-Święty, A.; Milewska-Wróbel, D.; Janicka, I. Dietary Strategies for Primary Prevention of Atopic Diseases-What Do We Know? Dev. Period Med. 2016, 20, 68-74. [PubMed] 